Preprints of the

Max Planck Institute for

Research on Collective Goods

Bonn 2017/22

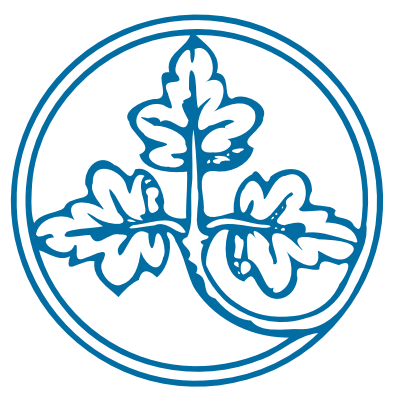

Measuring Indirect Effects of Unfair Employer Behavior on Worker Productivity

- A Field Experiment

Matthias Heinz

Sabrina Jeworrek

Vanessa Mertins

Heiner Schumacher

Matthias Sutter

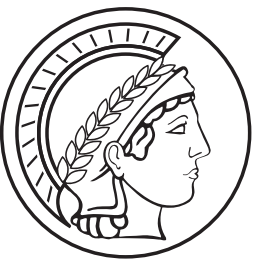




\section{Measuring Indirect Effects of Unfair Employer Behavior on Worker Productivity - A Field Experiment}

Matthias Heinz / Sabrina Jeworrek / Vanessa Mertins /

Heiner Schumacher / Matthias Sutter

November 2017 


\title{
Measuring Indirect Effects of Unfair Employer Behavior on Worker Productivity - A Field Experiment
}

\author{
Matthias Heinz ${ }^{1}$, Sabrina Jeworrek ${ }^{2}$, Vanessa Mertins ${ }^{3}$, \\ Heiner Schumacher ${ }^{4}$ and Matthias Sutter ${ }^{5}$
}

\section{November 3, 2017}

\begin{abstract}
We present a field experiment in which we set up a call-center to study how the productivity of workers is affected if managers treat their co-workers in an unfair way. This question cannot be studied in long-lived organizations since workers may change their career expectations (and hence effort) when managers behave unfairly towards co-workers. In order to rule out such confounds and to measure productivity changes of unaffected workers in a clean way, we create an environment where employees work for two shifts. In one treatment, we lay off parts of the workforce before the second shift. Compared to two different control treatments, we find that, in the layoff treatment, the productivity of the remaining, unaffected workers drops by 12 percent. We show that this result is not driven by peer effects or altered beliefs about the job or the managers' competence, but rather related to the workers' perception of unfair behavior of employers towards co-workers. The latter interpretation is confirmed in a survey among professional HR managers. We also show that the effect of unfair behavior on the productivity of unaffected workers is close to the upper bound of the direct effects of wage cuts on the productivity of affected workers. This suggests that the price of an employer's unfair behavior goes well beyond the potential tit-for-tat of directly affected workers.
\end{abstract}

Keywords: Gift exchange, Layoffs, Labor Markets, Fairness, Field Experiment

JEL: C93, J50, J63

Acknowledgment: We would like to thank Oriana Bandiera, Björn Bartling, Alexander Cappelen, Gary Charness, Stefano DellaVigna, Florian Englmaier, Guido Friebel, Simon Gächter, Oliver Hart, Bernd Irlenbusch, Supreet Kaur, Georg Kirchsteiger, Michael Kosfeld, Matthias Kräkel, Rocco Macchiavello, Dirk Sliwka, Jeroen van de Ven, Joel van der Weele, Ferdinand

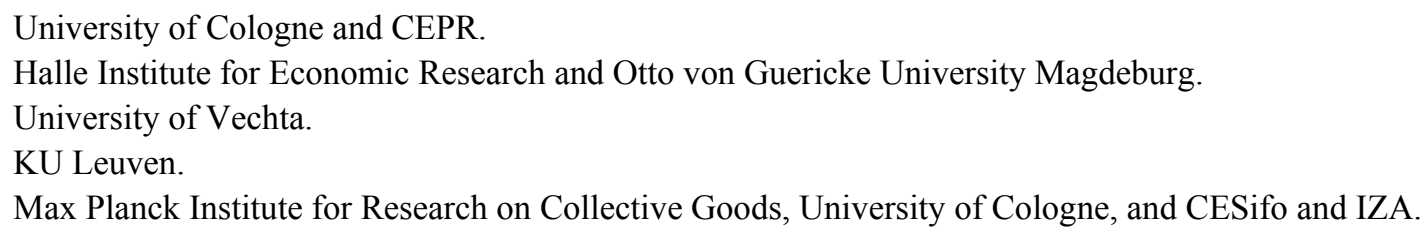


von Siemens, Bertil Tungodden, and Roberto Weber, as well as audiences at the Advances in Field Experiments Conference, Bristol Workshop on Economic Policy Intervention and Behavior, COPE, GfeW Meeting, Nordic Conference in Behavioral and Experimental Economics, North Conference on Behavioral Economics, NHH Bergen, University of Cologne, Goethe-University Frankfurt, KU Leuven, University of Mainz, Ludwig-Maximilians University Munich, and RWTH Aachen for valuable comments and discussions. We thank Andrew Kinder, Sebastian Koch, Uta Richter, and Anne-Sophie Ritterbeck for excellent research assistance. The usual disclaimer applies. 


\section{Introduction}

Management matters for the success and profitability of companies. Recent work has shown, for instance, that simple management practices - including regular maintenance of machines, optimization of inventory, or recording types of quality problems - can improve the productivity of companies substantially (Bloom et al., 2013). While many such management practices relate to the structure of an organization, in particular its workflow and the controlling thereof, the relationship between managers and workers is also of great importance. This relationship is not only characterized by the wage that is paid to a worker (as an incentive to work hard), but also by the worker's perception of being treated fairly. In fact, Akerlof's (1982) theory of gift exchange between employers and their workers not only referred to a generous wage as an employer's gift to the worker, but also to fair behavior of employers towards workers. A large body of field experiments (Harrison and List, 2004) has examined the gift exchange relationship between employers and employees. Typically, these experiments analyze the extent to which workers reciprocate wage raises or cuts, and frequently (but not always) find affirmative results by showing that employer generosity leads to higher work effort from employees, while the opposite is true if employers cut wages (Gneezy and List, 2006; Henning-Schmidt et al., 2010; Kube et al., 2012, 2013; Cohn et al., 2015; Gilchrist et al., 2015, DellaVigna et al., 2016; Esteves-Sorenson, forthcoming). As a result, and not surprisingly, the employers' behavior and the perception of it has consequences for the productivity of affected workers.

What remains much less clear is how the workers' productivity is influenced if the employers' behavior towards some co-workers changes. In other words, what happens to a specific worker's productivity in a firm when the employer or a manager treats co-workers in a fair or unfair way, while the specific worker is completely unaffected by the employer's behavior? Such situations are common in daily business life. For instance, a worker may observe how a manager praises or criticizes a co-worker, or how a manager fires another worker. A priori, it is not clear what kind of consequences to expect from an unaffected worker in such situations. In case of observing someone being fired for an unjustified reason, an unaffected worker may not react at all to the employer's behavior, since he or she simply keeps the job under the same conditions. Alternatively, the worker may reduce productivity because of judging the employer's behavior as unfair, thus retaliating with less work effort. Yet, also the opposite reaction may occur when the worker who keeps the job increases productivity as a sign of gratitude for not having been fired. For HR management, the direction of this indirect effect on unaffected workers matters a lot.

However, the scenario described above illustrates the difficulties that researchers face when studying the workers' response to unfair acts. The challenge is to confront workers with an unfair act by the employer towards co-workers, while keeping their own prospects in the organization constant. This is difficult to realize in a long-established organization since any unfair behavior may change the workers' career expectations and thus effort incentives. For example, workers may fear that similar acts may take place in the future, so that switching jobs becomes an attractive option, which in turn may reduce their motivation to exert effort. 
In this paper, we avoid such confounds, so that we can cleanly measure the productivity response of unaffected workers when employers behave unfairly towards co-workers. Our solution is to create our own short-lived organization with 195 employees. They work for us in a call-center to conduct a telephone survey in two separate shifts. Overall, our organization was very employee-friendly by paying a generous hourly wage, offering flexible work times, a pleasant work atmosphere, and full discretion to workers how to perform the job. Our field experiment allowed us to implement in one treatment an unfair action by the employer through laying off 20 percent of the workforce to cut costs - and to keep the remaining workers' prospects (in the only remaining shift) constant. To rule out any career concerns, we made very explicit, in several instances, that there would be no future employment possibilities in the organization. Moreover, we paid the wage upon arrival to each shift. Thus, workers knew at the beginning of the second shift that the layoff of their co-workers could not have any consequences for them. All of these measures are difficult or impossible to realize in ongoing organizations. The short-term nature of our organization is therefore an essential property and key asset of our field experiment.

In the experiment, we implemented three different treatments. In a standard control treatment, the staff remained unchanged for the second shift. In a second control treatment - called "Quasi-layoff" - we reduced our staff by 20 percent between shifts, but did not communicate the layoff to the remaining workers (we only informed them that fewer staff were present during the second shift). In the third treatment - called "Layoff" - we randomly dismissed 20 percent of the workers after the first shift and communicated the random layoff to the remaining workers as a measure to save costs. As a post-experimental questionnaire clearly revealed, this measure was seen as unfair both by the workers in the field experiment, but also by new experimental participants and by professional HR managers whom we recruited to gain more indepth insights into what drives productivity shocks in case of unfair employer behavior.

Our results show a very clear effect of layoffs that are perceived as unfair on the productivity of the remaining - and completely unaffected - workers. In our call-center, we have highquality data on the number of calls, the time spent on the phone and the number of interviews completed. Compared to the control treatments, productivity in our Layoff treatment drops by a statistically and economically significant amount of 12 percent. We also find evidence that the quality of the workers' output decreases through the unfair layoff. Importantly, there is no significant difference in performance between the two control treatments. Thus, the reduction in staff size per se has no effects on productivity. Further robustness checks reveal that our treatment differences are neither driven by peer-effects nor by altered beliefs about the importance of the job or the management's competence. Our robustness checks are not only based on a post-experimental survey with workers in the field experiment, but also on additional experiments with 212 university students and 43 professional HR managers in mediumsized and large companies in Germany. In these experiments, we find strong evidence that the announcement of random layoffs was considered as unfair. We also asked the HR managers to predict the workers' productivity response in our field experiment. It turns out that their predictions were remarkably accurate in the aggregate, showing that HR managers (who had on 
average almost eight years of professional experience) anticipate the detrimental effects of unfair behavior on the productivity of unaffected workers.

In order to put our results into perspective, we compare the observed effect sizes with the effects that wage cuts or increases have had on the productivity of affected workers in previous studies (like Gneezy and List, 2006, or Kube et al., 2013). Our effect size is at the upper bound of such previous studies, showing that unfair behavior of employers can have even larger negative effects on unaffected workers than when this behavior has a direct consequence on a specific worker. While we consider it as not very surprising that workers who are affected by unfair behavior (such as a wage cut under specific conditions) reduce their productivity, we find it remarkable that the indirect effects on unaffected workers can be equally strong.

So far, only a few studies are available that investigate such indirect effects as we do. Charness and Kuhn (2007) study in a laboratory experiment how worker productivity is affected by changes in their co-workers' wages, finding practically no externality of co-workers' wages. Cohn et al. (2014) conduct a field experiment in which workers perform a job in teams of two. In one treatment, they cut the fixed wage of one worker and leave the co-worker's wage unchanged. In their setting, the unaffected worker does not change his or her performance in response to the co-worker's wage cut. This may be due to the fact that the unaffected worker may not have perceived the co-worker's wage cut as unfair. Unfortunately, Cohn et al. (2014) do not have data on how the wage cut was perceived by the unaffected workers. In our field experiment, we can show that the layoff of co-workers is judged as unfair and that workers in the layoff treatment reduce their productivity significantly, despite being unaffected by the layoffs. Our second control treatment (the Quasi-layoff treatment) shows that the reduction in staff itself is not considered as unfair and does not have any effect on productivity, a result that is similar to the one in Cohn et al. (2014).

A recent field experiment by Breza et al. (forthcoming) examines productivity effects of pay inequality. In general, they observe that pay inequality reduces output by a considerable amount when productivity is difficult to observe, while it has almost no effect when it is observable and when pay inequality is well justified and understood by peers. The latter result indicates that workers have no problem with pay inequality per se, which is similar to the nullresults of a pure staff reduction (as in our Quasi-layoff treatment). When output is more difficult to measure, relatively lower-paid workers reduce their output substantially in reaction to pay inequality. Yet, they are directly affected by being paid relatively less, so that this is different from our focus. Breza et al. (forthcoming) also report indirect effects by observing that relatively higher-paid workers decrease work effort when they perceive pay inequality. While these relatively higher-paid workers were not directly affected by the lower pay for their coworkers, Breza et al. (forthcoming) note that "if lower-paid workers were discontent and resentful, then working and eating lunch alongside them may have been socially awkward or unpleasant for their relatively higher-paid peers, dampening their desire to go to work" (p. 27 in accepted manuscript). Thus, their situation is substantially different from ours as the higherpaid workers kept contact with the disadvantaged, lower-paid workers. Obviously, this had 
direct effects on the higher-paid workers' happiness and work attitude, and it might have changed their beliefs about the employers' future behavior, making it impossible to measure the indirect effects of employers' unfair behavior on unaffected workers. In our setting, the remaining workers did not have any contact with the unfairly treated (i.e., dismissed) coworkers in the second shift, as the laid-off workers were no longer present. This means that we provide a setting that avoids the potential confound of remaining workers being directly affected, and it tilts the odds against finding an effect of unfair employer behavior on the productivity of unaffected workers. This means that we can report causal evidence of a large drop in the productivity of unaffected workers in reaction to unfair employer behavior towards coworkers.

The rest of the paper is organized as follows. In Section 2, we explain the setup of the field experiment and a post-experimental survey among participants in the field experiment. Section 3 presents the results and examines several potential explanations for them. In Section 4, we present additional insights from running a vignette study with university students and an experiment with professional HR managers to explain our main finding. In Section 5, we put the size of our effect into perspective by comparing it to related studies on how worker productivity reacts to wage changes. Section 6 concludes and discusses implications for HR management. An Online Appendix contains additional material and robustness checks.

\section{Experimental setup}

\subsection{Field setting in the call-center}

We used the following opportunity for our field experiment. A German university intended to conduct a nationwide survey on refugee integration and engagement in volunteering. The survey consisted of a number of short questions (a translation can be found in the Online Appendix). We essentially took over the management of this survey by renting a call-center for eight weeks and recruiting workers in regional online and offline job markets. The job advertisement stated explicitly that the job consisted of conducting a telephone survey in two shifts and that there would be no future employment opportunities in the call-center. Applicants were required to have an e-mail address, a mobile phone number, and they had to speak German fluently. They applied online by uploading their résumé (or by completing a short form), indicating possible working times, and consenting to the storage and processing of the generated data. We hired all 195 applicants who met our requirements. ${ }^{6}$

The job comprised two work shifts of 3.5 hours each. The second shift was always scheduled exactly one week after the first. In each shift, three to five individuals worked simultaneously in single offices (a picture of a typical workplace is included in the Online Appendix). The fixed wage was 40 Euros per shift. As wages for unskilled workers in German call-centers are

6 Yet, we excluded applicants who were recommended by others whom we already had hired. This was done in order to avoid social ties between workers (see more details below). 
usually rather low (Bosch and Weinkopf, 2008) and the hourly wage in our organization was one third above the German minimum wage, we consider our wage as generous. In fact, in a post-experimental questionnaire (introduced below), our workers indicated that they were very satisfied with their wage.

The workers' job was to call phone numbers from a list generated by the Leibniz Institute for Social Sciences. For each phone number called, workers had to indicate on the list whether (i) the number does not exist (due to random generation), (ii) nobody answered the phone after ringing for 15 seconds, (iii) a telephone answering device answered the call, (iv) the line was busy, (v) the interviewers were asked to call back later on, (vi) an interview was denied, or (vii) an interview was completed. Workers could freely choose their pace and have breaks at their discretion.

The call-center IT supplied us with precise connection data, so that we have exact performance measures for each worker with respect to the total number of calls and the total time spent on the phone. ${ }^{7}$ On average, only one out of 50 dialed numbers led to an interview. Hence, for a single worker the number of actually completed interviews was rather low and noisy. Thus, we prefer the number of calls and the time spent on the phone as our primary performance measures. However, we will also present data on the number of completed interviews, and in further robustness checks (shown in the Online Appendix), we will also use alternative performance measures, i.e., the gross working time (the time between the first and the last phone call in a shift), the number of calls normalized by the time spent on interviews, and several self-reported performance measures.

\subsection{Experimental treatments in the call-center}

We have three treatments, which we call "No-layoff", "Quasi-layoff", and "Layoff". The first shift was identical in all treatments. After the first shift, we randomly selected 20 percent of the workers from the Layoff and Quasi-layoff treatments and asked them not to work for us during the second shift. ${ }^{8}$ In the No-layoff treatment, all workers remained employed for the second shift. To keep workers' prospects in the organization constant across treatments, we paid them their wage in all treatments at the beginning of each shift. If we had paid the wage at the end of a shift, workers in the Layoff and Quasi-Layoff treatment might have been concerned about the employer's reliability of actually paying the money after workers had learned about some co-workers' layoffs. This could have affected their beliefs about prospects and

$7 \quad$ We requested that workers let the phone ring for 15 seconds (with the clock running on the phone's display). We rate an event as a call (or time spent on the phone) if (i) the number existed and (ii) the call time was at least 15 seconds or a client/answering device picked up the phone. In the Online Appendix, we show that our results remain unchanged when we vary the 15 -second threshold. The total time spent on the phone includes the time spent dialing the number. Similar performance measures have been used in previous call-center studies (e.g., Friebel and Seabright, 2011, or Bloom et al., 2015).

8 Specifically, we called them two days before their second shift. For ethical reasons, we paid these workers the promised 40 Euros for the participation in a survey a few weeks after the field experiment. They were unaware about this when they received the layoff message. Moreover, we debriefed them about the field experiment and their role after the completion of all experiments. 
hence their work effort. By paying in advance, we can rule out this potential confound when comparing efforts across treatments.

We communicated the layoffs to the remaining workers in a two-step procedure. The day before the second shift, we sent workers in the different treatments the following messages, shown in Figure 1, via e-mail (originally in German):

\section{No-layoff treatment}

Dear Interviewer,

We are happy that so many of you supported our country-wide survey on refugee integration: more than 50 interviewers worked for us.

There will be no organizational changes tomorrow.

We would like to remind all interviewers about their second shift. Please arrive at the callcenter on time. A colleague will guide you to your office.

As we said earlier, this appointment is your last employment in our project. We can only offer you to work for us in two shifts of 3.5 hours each. We hope that you will understand.

\section{Quasi-layoff and Layoff treatments}

Dear Interviewer,

We are happy that so many of you supported our country-wide survey on refugee integration: more than 50 interviewers worked for us.

There will be no organizational changes tomorrow, except that we will have 20 percent fewer staff.

We would like to remind all interviewers about their second shift. Please arrive at the callcenter on time. A colleague will guide you to your office.

As we said earlier, this appointment is your last employment in our project. We can only offer you to work for us in two shifts of 3.5 hours each. We hope that you will understand.

Figure 1: Messages to workers before the second shift

The message works as a simple reminder and (again) makes clear that there are no future employment opportunities in our organization. When workers arrived for their second shift, they received the following message, shown in Figure 2, conditional on the treatment, as a printed note on their desk: 


\section{No-layoff treatment}

Please do not advertise this job to others any longer, we have enough workers!
Please do not advertise this job to others any longer, we have enough workers!

Due to organizational reasons, we already have $20 \%$ fewer staff.

\section{Layoff treatment}

Please do not advertise this job to others any longer, we have enough workers!

Due to organizational reasons, we already have $20 \%$ fewer staff.

The reason for this is that we decided to lay off some of your colleagues. This allows us to reduce costs. The selection of laid-off workers has been random.

Figure 2: Message to workers at the start of second shift

The first sentence contained a natural message for the workers since, during the first shift, a number of them had recommended family members and friends to us as suitable workers (but we never hired any of them). The second sentence in the Layoff and Quasi-layoff treatments provides a partial justification for our request not to advertise the job to others. The last part of the message for the Layoff treatment is central for our purpose. It informs workers about the layoffs, as well as why and how they took place. In particular, it mentions that the layoffs were random (making it clear that they were not based on productivity in the first shift) and that they helped us to reduce costs (which was correct since we had to pay less to the call-center when we used fewer offices). This message was in clear contrast to the generous employer behavior towards workers by paying more than the market salaries and providing a relaxed work space and working conditions. The message makes it salient that the employer is concerned with labor costs and prioritizes cost reductions over employee welfare and the random determination of the layoffs indicated unfair behavior on the employer's side. Indeed, a significant literature (e.g., Datta et al., 2010; Drzensky and Heinz, 2016) uses surveys and lab experiments to show that laying off workers is an extremely unpopular measure.

In preparation for the field experiment, we registered the project at the AEA RCT Registry (ID: AEARCTR-0001075) and applied for an ethical approval from the Independent Review Board of Trier University (where two authors were affiliated when we started our study). We received the approval without any restrictions. Using phone data from the experiment in Chadi et al. (2016), we calculated that we would need around 50 observations in each treatment to detect a 10-percent treatment effect at the 5-percent significance level with a probability of 80 percent. 


\subsection{Post-experimental survey and debriefing}

Post-experimental survey. Six weeks after the completion of the field experiment, we invited all call-center workers to participate in a survey in which we measured their beliefs and perceptions during their job. Moreover, we evaluated participants' work satisfaction. Subjects were paid 15 Euros for their participation. In total, 75.9 percent of the workers who worked in both shifts participated in the survey.

Debriefing. Two months after the completion of the online survey, we debriefed all workers (including those we had laid off), informed them that the job at the call-center was part of an experiment, and invited them to answer a few questions related to the field experiment. Specifically, we asked workers about the extent to which they expected negative consequences for themselves when having learned about co-workers' layoffs, their perceptions of the layoff information and of the management's competence, their beliefs about the importance of the job, and their social network. To get precise data on the social network in our workforce, we asked workers in an incentive-compatible way whether they knew any co-workers from the callcenter. For each correct name, we paid them 0.50 Euros. We also asked the remaining workers from the Layoff treatment about how they evaluated the individual statements contained in the layoff announcement. In total, 76.3 percent of the workers who were employed in both shifts responded to our questions in the debriefing. 


\begin{tabular}{|c|c|c|c|c|c|}
\hline & $\begin{array}{l}\text { Layoff } \\
(\mathrm{n}=61)\end{array}$ & $\begin{array}{l}\text { Quasi- } \\
\text { layoff } \\
(=56)\end{array}$ & $\begin{array}{l}\text { No-layoff } \\
\qquad(n=45)\end{array}$ & $\begin{array}{l}\text { Layoff vs. } \\
\text { Quasi-layoff } \\
\text { (p-value) }\end{array}$ & $\begin{array}{c}\text { Layoff vs. } \\
\text { No-layoff } \\
\text { (p-value) }\end{array}$ \\
\hline \multicolumn{6}{|c|}{ Panel A: Performance in first shift } \\
\hline $\begin{array}{l}\text { Number of calls } \\
\text { (call time }>15 \text { seconds) }\end{array}$ & $\begin{array}{c}92.3 \\
(22.9)\end{array}$ & $\begin{array}{c}88.9 \\
(26.9)\end{array}$ & $\begin{array}{c}87.4 \\
(21.9)\end{array}$ & 0.459 & 0.262 \\
\hline Total call time (in minutes) & $\begin{array}{c}91 \\
(25.2)\end{array}$ & $\begin{array}{c}91.8 \\
(24.3)\end{array}$ & $\begin{array}{c}84.8 \\
(23.1)\end{array}$ & 0.862 & 0.188 \\
\hline Gross working time (in minutes) & $\begin{array}{l}206 \\
(9.0)\end{array}$ & $\begin{array}{l}208.5 \\
(10.1)\end{array}$ & $\begin{array}{c}206.1 \\
(9.0)\end{array}$ & 0.162 & 0.966 \\
\hline $\begin{array}{l}\text { Amount of dialed numbers (self- } \\
\text { reported; existing \& non-existing) }\end{array}$ & $\begin{array}{l}243.2 \\
(66.9)\end{array}$ & $\begin{array}{l}238.7 \\
(68.1)\end{array}$ & $\begin{array}{l}230.4 \\
(57.1)\end{array}$ & 0.718 & 0.283 \\
\hline $\begin{array}{l}\text { Amount of dialed numbers (self- } \\
\text { reported; only existing numbers) }\end{array}$ & $\begin{array}{l}104.9 \\
(28.8)\end{array}$ & $\begin{array}{l}106.2 \\
(29.0)\end{array}$ & $\begin{array}{l}104.8 \\
(26.7)\end{array}$ & 0.807 & 0.984 \\
\hline $\begin{array}{l}\text { Number of interviews } \\
\text { (self-reported) }\end{array}$ & $\begin{array}{c}5.1 \\
(2.6)\end{array}$ & $\begin{array}{c}5.3 \\
(2.0)\end{array}$ & $\begin{array}{c}4.8 \\
(2.5)\end{array}$ & 0.727 & 0.510 \\
\hline $\begin{array}{l}\text { Number of interviews (self- } \\
\text { reported; call-time }>\text { one min.) }\end{array}$ & $\begin{array}{l}4.8 \\
(2.6)\end{array}$ & $\begin{array}{c}5.0 \\
(2.2)\end{array}$ & $\begin{array}{l}4.6 \\
(2.2)\end{array}$ & 0.626 & 0.618 \\
\hline $\begin{array}{l}\text { Completion of an interview } \\
\text { (in percent) }\end{array}$ & $\begin{array}{c}17.6 \\
(11.2)\end{array}$ & $\begin{array}{c}18 \\
(9.4)\end{array}$ & $\begin{array}{l}16.6 \\
(9.0)\end{array}$ & 0.859 & 0.62 \\
\hline \multicolumn{6}{|c|}{ Panel B: Worker Characteristics } \\
\hline Age & $\begin{array}{l}26.3 \\
(8.2)\end{array}$ & $\begin{array}{c}29.9 \\
(13.0)\end{array}$ & $\begin{array}{l}27.0 \\
(8.9)\end{array}$ & 0.296 & 0.855 \\
\hline Female (in percent) & 63.9 & 64.3 & 56.8 & 0.968 & 0.451 \\
\hline Nationality: Germany (in percent) & 91.8 & 91.1 & 90.1 & 0.888 & 0.872 \\
\hline Student (in percent) & 57.4 & 50.0 & 50.0 & 0.424 & 0.454 \\
\hline University degree (in percent) & 14.8 & 14.3 & 6.8 & 0.943 & 0.207 \\
\hline Unemployed (in percent) & 21.3 & 14.3 & 34.1 & 0.323 & 0.144 \\
\hline Vocational training (in percent) & 24.6 & 21.4 & 18.2 & 0.685 & 0.433 \\
\hline Full- or part-time job (in percent) & 39.3 & 42.9 & 29.5 & 0.700 & 0.300 \\
\hline $\begin{array}{l}\text { Previous employment similar to } \\
\text { call-center job (in percent) }\end{array}$ & 30.4 & 27.5 & 23.5 & 0.741 & 0.483 \\
\hline $\begin{array}{l}\text { Regular employment on a } \\
\text { short-term basis (in percent) }\end{array}$ & 55.3 & 55.3 & 42.8 & 1.000 & 0.296 \\
\hline
\end{tabular}

Data sources: the IT data from the call-center (source 1); the number lists on which workers indicated the outcome from each phone call (source 2); the workers' résumés and a form that workers completed prior to their first shift in the call-center (source 3); the post-experimental survey (source 4). In Panel A, we use data from source 1 for the first three variables (and partly for the seventh variable) and from source 2 for the remaining variables. In Panel B, we use data from source 3 for the first nine variables and from source 4 for the last variable. Definition of variables: Vocational training means that a worker 
has completed a vocational training or is enrolled in a vocational training at the time when the study took place. Full-time or part-time job means that a subject has a full- or part-time job at the time of the study (we did not count mini jobs as full- or part-time jobs). Regular employment on a short-term basis means that a subject's reply was "yes" to the question: "Did you have similar short-term jobs like the one in the call-center in Saarbruecken in the past two years (e.g. short term employment in construction or agriculture)?" Missing observations: Source 2: We dropped one observation in the Layoff treatment. The subject did not make notes about her phone calls on the list in the first shift. Source 3: We have no data for two subjects as they neither submitted their résumé nor participated in the survey. For 20 subjects the employment data are missing, as they did not submit their résumés. No Layoff treatment: In two shifts, the IT in the call-center did not record the phone data. For our analysis, we drop the data from the subjects who worked in these two shifts. Our treatment groups are still balanced if we include the data from the omitted subjects. In the Online Appendix, we show that our main regression results (Tables $E$ and $F$ ) are the same when we use the self-reported performance data as dependent variable and include the data from the omitted subjects. Statistical tests: In column 5 and 6 , we report p-values of either two-sided t-tests (Panel A) or two-sided Mann-Whitney ranksum tests (Panel B) for non-binary variables. For binary variables, we use a Chi-square test.

\section{Results}

\subsection{Descriptive statistics and randomization checks}

In total, we had 52 workers in the No-layoff treatment; ${ }^{9} 69$ in the Quasi-layoff treatment, of whom 13 were laid off; and 74 in the Layoff treatment, of whom 13 were laid off. ${ }^{10}$ In the following, we ignore the laid-off workers. ${ }^{11}$ The field experiment took 35 working days within a period of eight weeks. The selection into treatments was random. ${ }^{12}$ Table 1 summarizes for each treatment the surviving workers' characteristics and their performance in the first shift. Workers were between 16 and 65 years old (mean $=27.8, \mathrm{sd}=10.4), 62.1$ percent were female, and 91.8 percent were born in Germany. The sample was quite heterogeneous in terms of education and employment status. Half of them were students at university, and a quarter consisted of unemployed individuals. Around 50 percent indicated that they were regularly employed in short-term jobs similar to the one in the call-center.

During the first shift, workers called on average 89.9 (existing) numbers ( $\mathrm{sd}=23.8)$ and spent 89.8 minutes on the phone $(\mathrm{sd}=24.3)$. There are no economically or statistically significant

9 This number includes seven workers for whom we lost the second-shift phone data (due to IT problems). All of them worked in the No-layoff treatment. We dropped them from the sample. Our treatment groups are still balanced if we include their data. Moreover, if we include these workers in the dataset, our results for the self-reported data are unchanged; see Tables E and F in the Online Appendix.

10 We had to decide about the number of layoffs before we knew the number of workers who returned for the second shift. We had anticipated a slightly higher dropout rate than was actually realized, and hence laid off one or two fewer workers in the Layoff treatment than we should have to meet the 20-percent level. Overall, only five subjects (who were not laid off) did not show up for the second shift, which explains the slightly lower layoff rate.

11 In Table $\mathrm{N}$ of the Online Appendix, we show that there are no significant differences in the characteristics of laid-off workers and remaining workers.

12 In the No-layoff treatment, 75 percent of workers were employed during the first two weeks, and the remaining 25 percent in the last six weeks. Workers in the Quasi-layoff and Layoff treatments were employed in the last six weeks. We chose this procedure to minimize potential spillover effects; see the discussion in subsection 3.4. 
differences in performance between treatments (see Panel A of Table 1). This is also true for personal characteristics (Panel B). Thus, our worker sample is balanced and randomization worked well.
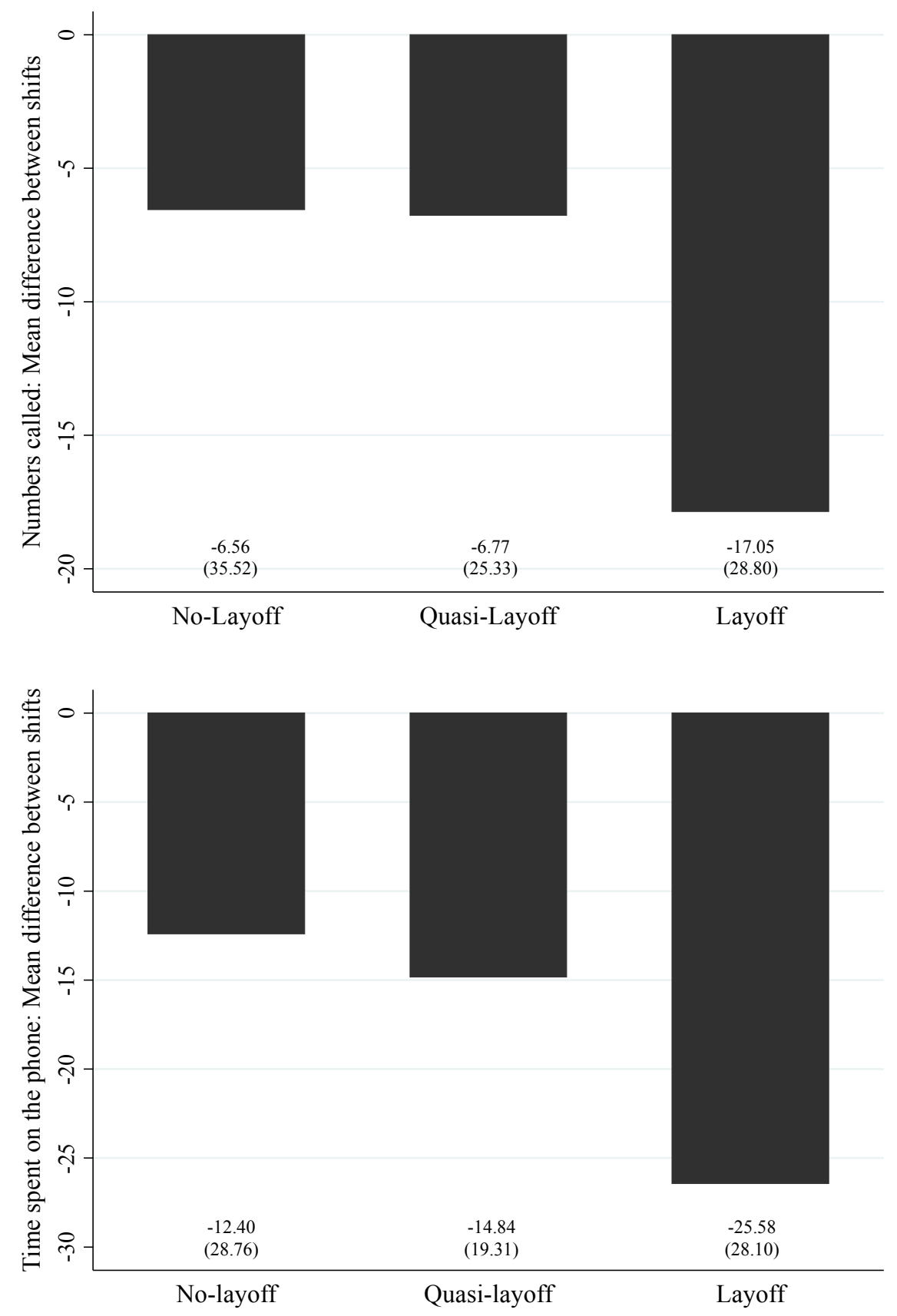

Figure 3: Difference in performance between second and first shift. Upper panel: numbers called. Lower panel: time spent on phone. 


\subsection{Main results}

Our main research question is whether workers respond to the announcement of unfair layoffs by exerting less effort. Figure 3 displays how worker performance changes between the first and second shift. We observe that performance drops significantly in all treatments. However, in the Layoff treatment, the reduction is much larger than in the No-layoff and Quasi-layoff treatments. The average number of calls decreases by around 8 percent in the No-layoff and Quasi-layoff treatments, but by 19 percent in the Layoff treatment (No-layoff versus Quasilayoff treatment, t-test $\mathrm{p}$-value $=0.972$; Quasi-layoff versus Layoff treatment, $\mathrm{t}$-test $\mathrm{p}$-value $=$ 0.031; No-layoff versus Layoff treatment, t-test $p$-value $=0.072){ }^{13}$ The time spent on the phone decreases by around 16 percent in the No-layoff and Quasi-layoff treatments, but by 29 percent in the Layoff treatment (No-layoff versus Quasi-layoff treatment, t-test p-value = 0.613; Quasi-layoff versus Layoff treatment, t-test $\mathrm{p}$-value $=0.012$; No-layoff versus Layoff treatment, t-test $\mathrm{p}$-value $=0.015$ ).

We compare the performance reductions between treatments in several different regression frameworks. First, we estimate the effect of layoffs on the workers' performance in the following difference-in-difference specification:

$$
y_{i}=\beta_{0}+\beta_{1} \text { No-layoff }_{i}+\beta_{2} \text { Layoff }_{i}+\beta_{3} t+\beta_{4} \text { No-layoff }_{i} \times t+\beta_{5} \text { Layoff }_{i} \times t+\varepsilon_{i} \text {, }
$$

where $y_{i}$ is the performance - number of calls or time spent on phone - of subject $i$. The shift dummy $t$ is 0 for the first and 1 for the second shift. The variables Layoff $i$ and No-layoff $i$ are dummies that are set to 1 for the corresponding treatment (the Quasi-layoff treatment serves as the baseline), and $\varepsilon_{i}$ is the idiosyncratic error term. In our second specification, we additionally control for subjects' age, gender, nationality, educational background (university degree, vocational training, etc.), and current employment status (regular job, student, unemployed). In the third specification, we additionally include dummies for each of the 35 working days and dummies for the working time (morning, noon, afternoon). In the fourth specification, we omit the controls, but include a subject fixed effect. In the fifth specification, we estimate a generalized difference-in-difference model to control for regression to the mean:

$$
y_{i 1}=\beta_{0}+\beta_{1} \text { No-Layoff } i+\beta_{2} \text { Layoff }_{i}+\beta_{3} y_{i 0}+\varepsilon_{i}
$$

The variable $y_{i 0}\left(y_{i 1}\right)$ denotes worker $i$ 's performance in the first (second) shift. Finally, in the sixth specification, we estimate a regression model where we use the difference in performance between the second and first shift as the dependent variable:

$$
y_{i 1}-y_{i 0}=\beta_{0}+\beta_{1} \text { No- }_{\text {Layoff }}+\beta_{2} \text { Layoff }_{i}+\varepsilon_{i} \text {. }
$$

In the first four specifications, standard errors are clustered on the subject level; in the last two specifications, they are clustered on the day-shift level.

13 All tests in this paper are two-sided. For our performance measures, we use t-tests, since data are roughly normally distributed. 
Table 2: Baseline Regression: Number of Calls

\begin{tabular}{|c|c|c|c|c|c|c|}
\hline \multirow[b]{2}{*}{ Specification } & \multicolumn{4}{|c|}{ Number of calls } & \multirow{2}{*}{$\begin{array}{c}\text { Numbers } \\
\text { called } t_{2} \\
(5)\end{array}$} & \multirow{2}{*}{$\begin{array}{c}\text { Difference } \\
\mathbf{t}_{\mathbf{2}}-\mathbf{t}_{1} \\
(6)\end{array}$} \\
\hline & (1) & (2) & (3) & (4) & & \\
\hline Constant & $\begin{array}{c}88.929 * * * \\
(3.597)\end{array}$ & $\begin{array}{c}83.060 * * * \\
(12.052)\end{array}$ & $\begin{array}{c}69.405 * * * \\
(17.692)\end{array}$ & $\begin{array}{c}89.770 * * * \\
(1.157)\end{array}$ & $\begin{array}{l}18.171 * \\
(9.341)\end{array}$ & $\begin{array}{c}-6.768^{*} \\
-3.621\end{array}$ \\
\hline $\mathrm{t}$ & $\begin{array}{c}-6.768 * * \\
(3.391)\end{array}$ & $\begin{array}{l}-6.768 * \\
(3.435)\end{array}$ & $\begin{array}{l}-9.482 \\
(7.565)\end{array}$ & $\begin{array}{c}-6.767 * * \\
(3.380)\end{array}$ & & \\
\hline No-layoff & $\begin{array}{l}-1.506 \\
(4.857)\end{array}$ & $\begin{array}{l}-1.454 \\
(5.221)\end{array}$ & $\begin{array}{l}-19.096 \\
(11.577)\end{array}$ & & $\begin{array}{l}-0.210 \\
(8.363)\end{array}$ & $\begin{array}{l}0.212 \\
-8.45\end{array}$ \\
\hline No-layoff × $\mathrm{t}$ & $\begin{array}{c}0.212 \\
(6.162)\end{array}$ & $\begin{array}{c}0.212 \\
(6.242)\end{array}$ & $\begin{array}{c}-3.513 \\
(10.273)\end{array}$ & $\begin{array}{c}0.212 \\
(6.142)\end{array}$ & & \\
\hline Layoff & $\begin{array}{c}3.388 \\
(4.597)\end{array}$ & $\begin{array}{c}2.900 \\
(4.530)\end{array}$ & $\begin{array}{c}8.141 \\
(9.252)\end{array}$ & & $\begin{array}{l}-9.332 * \\
(5.552)\end{array}$ & $\begin{array}{r}-10.282 * \\
(5.300)\end{array}$ \\
\hline Layoff $\times \mathrm{t}$ & $\begin{array}{c}-10.282^{* *} \\
(5.039)\end{array}$ & $\begin{array}{c}-10.282 * * \\
(5.104)\end{array}$ & $\begin{array}{c}-19.295^{* * *} \\
(7.331)\end{array}$ & $\begin{array}{c}-10.282^{* *} \\
(5.023)\end{array}$ & & \\
\hline Numbers called $t_{1}$ & & & & & $\begin{array}{c}0.719 * * * \\
(0.099)\end{array}$ & \\
\hline $\mathrm{R}^{2}$ & 0.040 & 0.093 & 0.228 & 0.036 & 0.270 & 0.029 \\
\hline Sample size & 322 & 322 & 322 & 322 & 161 & 161 \\
\hline Subject fixed effect & No & No & No & Yes & No & No \\
\hline Age, Age squared & No & Yes & Yes & No & No & No \\
\hline Female & No & Yes & Yes & No & No & No \\
\hline German & No & Yes & Yes & No & No & No \\
\hline Student & No & Yes & Yes & No & No & No \\
\hline University degree & No & Yes & Yes & No & No & No \\
\hline Regular job & No & Yes & Yes & No & No & No \\
\hline Vocational training & No & Yes & Yes & No & No & No \\
\hline Unemployed & No & Yes & Yes & No & No & No \\
\hline Working day & No & No & Yes & No & No & No \\
\hline Time of day & No & No & Yes & No & No & No \\
\hline
\end{tabular}

OLS regressions. In specifications (1) - (4), the dependent variable is the number of calls. In specification (5), the dependent variable is the number of calls in the second shift, and in specification (6) the dependent variable is the difference in the number of calls between the second and first shift. We only count phone calls if (i) the number is from the list of phone numbers that workers received and (ii) the phone rang for at least for 15 seconds (in case neither a telephone answering device nor a client picked up the phone while it was ringing). In a rare number of cases (less than 2 percent of all phone calls), workers received an incoming call from a client who had been called in the past. We count those phone calls as regular phone calls. If we exclude these phone calls, our main results are unchanged. The shift dummy $t$ is set to zero (one) for the first (second) shift. No-Layoff and Layoff are treatment dummies set to one for the corresponding treatment (and zero otherwise). Female, German, Student, University degree, Regular job, Vocational training and Unemployed are dummies. Working day is a 
dummy that is set to one for the day on which a worker worked in the call-center (and zero otherwise). Time of day are three dummies - one for the morning ( $8 \mathrm{am}$ to $12 \mathrm{am}$ ), the noon (12 am to $4 \mathrm{pm}$ ) and evening (4 pm to $8 \mathrm{pm}$ ). One subject worked between $10 \mathrm{am}$ and 1:30 pm in one shift. The $R$ square in specification (5) is the overall $R$ square. Standard errors are clustered on the subject level in specifications (1) - (4) and on the day-shift level in specifications (5) and (6). ${ }^{*} p<0.1,{ }^{* *} p<0.05,{ }^{* * *} p<0.01$.

Table 2 shows the regression results for the number of calls. We observe three important patterns. First, in all treatments, workers make fewer calls in the second shift than in the first shift. Second, the reduction is almost identical between the No-layoff and Quasi-layoff treatment (around 6 percent). Third, the reduction in performance is much stronger in the Layoff treatment. We estimate that the layoff announcement reduces the number of calls by around 12 percent compared to the other treatments. The magnitude of these effects is roughly the same in all specifications. 
Table 3: Baseline Regression: Total Time Spent on the Phone

\begin{tabular}{|c|c|c|c|c|c|c|}
\hline \multirow[b]{2}{*}{ Specification } & \multicolumn{4}{|c|}{ Total time spent on the phone } & \multirow{2}{*}{$\begin{array}{c}\text { Working } \\
\text { time }_{2} \\
(5)\end{array}$} & \multirow{2}{*}{$\begin{array}{c}\text { Difference } \\
\mathbf{t}_{2}-\mathbf{t}_{1} \\
(6)\end{array}$} \\
\hline & (1) & (2) & (3) & (4) & & \\
\hline Constant & $\begin{array}{c}91.794 * * * \\
(3.379)\end{array}$ & $\begin{array}{c}70.638 * * * \\
(10.651)\end{array}$ & $\begin{array}{c}48.549 * * * \\
(16.446)\end{array}$ & $\begin{array}{c}89.534 * * * \\
(1.007)\end{array}$ & $\begin{array}{c}4.994 \\
(9.050)\end{array}$ & $\begin{array}{c}-14.837 * * * \\
(2.874)\end{array}$ \\
\hline $\mathrm{t}$ & $\begin{array}{c}-14.837 * * * \\
(2.585)\end{array}$ & $\begin{array}{c}-14.837 * * * \\
(2.619)\end{array}$ & $\begin{array}{c}-19.735^{* * *} \\
(5.708)\end{array}$ & $\begin{array}{c}14.837 * * * \\
(2.577)\end{array}$ & & \\
\hline No-layoff & $\begin{array}{l}-7.017 \\
(4.827)\end{array}$ & $\begin{array}{l}-4.406 \\
(5.032)\end{array}$ & $\begin{array}{c}11.910 \\
(12.235)\end{array}$ & & $\begin{array}{c}0.919 \\
(6.695)\end{array}$ & $\begin{array}{c}2.435 \\
(6.582)\end{array}$ \\
\hline No-layoff $\times \mathrm{t}$ & $\begin{array}{c}2.435 \\
(5.006)\end{array}$ & $\begin{array}{c}2.435 \\
(5.071)\end{array}$ & $\begin{array}{c}11.495 \\
(11.527)\end{array}$ & $\begin{array}{c}2.435 \\
(4.990)\end{array}$ & & \\
\hline Layoff & $\begin{array}{l}-0.802 \\
(4.612)\end{array}$ & $\begin{array}{c}0.877 \\
(4.392)\end{array}$ & $\begin{array}{l}-2.917 \\
(7.779)\end{array}$ & & $\begin{array}{c}-10.913^{* *} \\
(4.555)\end{array}$ & $\begin{array}{c}-10.739 * * \\
(4.827)\end{array}$ \\
\hline Layoff $\times \mathrm{t}$ & $\begin{array}{c}-10.739 * * \\
(4.463)\end{array}$ & $\begin{array}{c}-10.739 * * \\
(4.521)\end{array}$ & $\begin{array}{c}-13.175^{* *} \\
(5.677)\end{array}$ & $\begin{array}{c}-10.739 * * \\
(4.449)\end{array}$ & & \\
\hline Working time $\mathrm{t}_{1}$ & & & & & $\begin{array}{c}0.784 * * * \\
(0.092)\end{array}$ & \\
\hline $\mathrm{R}^{2}$ & 0.113 & 0.212 & 0.315 & 0.103 & 0.382 & 0.050 \\
\hline Sample size & 322 & 322 & 322 & 322 & 161 & 161 \\
\hline Subject fixed effect & No & No & No & Yes & No & No \\
\hline Age, Age squared & No & Yes & Yes & No & No & No \\
\hline Female & No & Yes & Yes & No & No & No \\
\hline German & No & Yes & Yes & No & No & No \\
\hline Student & No & Yes & Yes & No & No & No \\
\hline University degree & No & Yes & Yes & No & No & No \\
\hline Regular job & No & Yes & Yes & No & No & No \\
\hline Vocational training & No & Yes & Yes & No & No & No \\
\hline Unemployed & No & Yes & Yes & No & No & No \\
\hline Working day & No & No & Yes & No & No & No \\
\hline Time of day & No & No & Yes & No & No & No \\
\hline
\end{tabular}

Similar OLS regression as in Table 2. The dependent variable is the number of minutes a worker spent on the phone. We only count phone calls if (i) the number is from the list of phone numbers that workers received and (ii) the phone rang for at least for 15 seconds (in case neither a telephone answering device nor a client picked up the phone while it was ringing). We count incoming phone calls (less than 2 percent of all phone calls) as regular phone calls. If we exclude incoming phone calls, our main results are unchanged. ${ }^{*} p<0.1,{ }^{\star *} p<0.05,{ }^{\star \star \star} p<0.01$. 
In Table 3, we present the regression results when performance is measured by the total time spent on the phone. We find similar results as for the number of calls. After the layoff announcement, workers spend around 12 percent less time on the phone compared to the other treatments.

A number of robustness checks confirm our results. Specifically, we use several alternative performance measures: the number of calls (time spent on the phone) without the 15 -second call time threshold or with a call time threshold of 30 seconds, the number of calls (time spent on the phone) normalized by the number of interviews, ${ }^{14}$ the gross working time, the total number of conducted interviews, and several self-reported performance measures. The results are presented in the Online Appendix. In all regressions, the announcement of unfair layoffs reduces performance by around 12 or more percent.

Main Result. Workers respond to the announcement of unfair layoffs by decreasing their performance (number of calls, time spent on the phone) by 12 percent. The mere announcement of the reduced staff size has no effect on the workers' performance.

There are two further noteworthy patterns when we compare worker performance across treatments. First, we observe that the drop in performance in the Layoff treatment is related to a reduction in what we call "gross working time". It is defined as the exact duration between the time when workers dial the first number and the time when they put down the phone the last time. If we re-run our baseline regression using gross working time as a dependent variable, we find that it is 12 percent smaller in the Layoff treatment than in the other treatments; see Table $\mathrm{H}$ in the Online Appendix. It seems that workers in the Layoff treatment did not take longer breaks during the second shift. Instead, they called the first existing phone number around 8 minutes later and stopped calling numbers around 12 minutes earlier in the Layoff treatment compared to the other treatments. ${ }^{15}$

Second, we find a treatment difference in the likelihood with which workers were able to conduct and complete an interview on the phone. When a call is answered, workers have to persuade their conversation partner to participate in the survey. Hence, the completion of an interview can be interpreted as an indicator of a worker's quality of output. The probability of completing an interview in the first shift is $17.4(\mathrm{sd}=10.0)$ percent and statistically the same in all treatments. In the second shift, this probability differs between treatments: it is $15.3 \mathrm{sd}=$ 9.3) percent in the Layoff treatment and $20.4(\mathrm{sd}=12.8)$ percent in the Quasi-layoff treatment (Layoff versus Quasi-layoff treatment, t-test $p$-value $=0.017$ ). When we re-run our baseline regression, using the probability of completing an interview as dependent variable, we find a statistically significant decrease in the Layoff treatment compared to the Quasi-layoff treat-

14 Interviews took around five minutes. During this time, no other calls could be made. Therefore, the normalized number of calls (time spent on the phone) is defined here as the number of calls (time spent on the phone) divided by the total working time excluding interview time.

15 From the call-center IT we know at what time a worker called the first and the last existing number. We use this as proxy for the actual beginning and end of the working time (we do not know the exact time when workers dialed the first or last number since that could have been a non-existent number). 
ment; see Tables $\mathrm{J}$ and $\mathrm{K}$ in the Online Appendix. Thus, we find some evidence that after the layoff announcement workers exert less effort to persuade their interviewees. This indicates that the layoff announcement not only affects the gross working time, but also the performance during this working time.

\subsection{How did workers perceive their employer and the layoff announcement?}

To study how workers perceived the employer's behavior as a potential explanation of our main result, we asked them in the post-experimental survey how satisfied they were (i) with the working atmosphere in the call-center, (ii) the wage, (iii) the manager's behavior towards the worker him- or herself, and (iv) the manager's behavior towards the worker's colleagues. The scale ranged from 0 (not satisfied at all) to 10 (very satisfied).

Overall, workers were quite satisfied with the job at the call-center. The mean score for the first question was 9.1 points $(\mathrm{sd}=1.6)$, and for the second question 9.1 points $(\mathrm{sd}=1.3)$. There are no significant differences between treatments for these questions (all t-test p-values $>$ $0.120)$. Also, the manager's behavior towards workers themselves was rated equally well in all treatments $($ mean $=9.3, \mathrm{sd}=1.6$, all t-test $\mathrm{p}$-values $>0.617$ ). However, the management's behavior towards a worker's colleagues was evaluated differently across treatments: the mean score for the fourth question is 9.3 points $(\mathrm{sd}=1.4)$ in the No-layoff treatment, 9.3 points $(\mathrm{sd}=$ 1.3) in the Quasi-layoff treatment, but only 8.7 points $(\mathrm{sd}=2.3)$ in the Layoff treatment (t-test for comparing Layoff and Quasi-layoff treatment: $\mathrm{p}$-value $=0.096)$. In Table $\mathrm{M}$ in the Online Appendix, we regress the satisfaction score for the manager's behavior toward co-workers in a Tobit regression on dummies for the Layoff and No-layoff treatment. We estimate that this score is around 10 percent lower in the Layoff compared to the Quasi-layoff treatment. The effect is significant at the 5-percent or 10-percent level, depending on the specification. Thus, in the Layoff treatment, workers were significantly less satisfied with the manager's behavior towards their co-workers than in the other treatments.

Next, we examine which contents of the layoff announcement were seen as anti-social in the Layoff treatment. To find out, we asked workers in this treatment the following question in the debriefing: "To what extent did you perceive the following parts of the message as anti-social, on a scale between 1 (not anti-social at all) to 10 (very anti-social)?" The items corresponded to (i) layoffs per se, (ii) layoffs to reduce costs, (iii) cost savings per se, and (iv) the random selection of workers. Layoffs per se received an average rating of 6.5 points $(s d=2.9)$, the layoffs to reduce costs 5.8 points $(\mathrm{sd}=2.8)$, the cost savings 5.2 points $(\mathrm{sd}=2.6)$, and the random selection of workers 6.1 points $(\mathrm{sd}=3.4)$. Thus, it seems that layoffs per se and the random selection of workers were perceived as particularly anti-social. In the following subsection, we examine several other potential explanations. 


\subsection{Examining alternative explanations for our main results}

Did workers expect future negative consequences after the announcement of the unfair layoffs? One crucial design feature for the analysis of our research question is that the remaining workers' expectations about their prospects in the organization must be held constant across treatments. We therefore paid all workers their wage at the beginning of each work shift and emphasized repeatedly that there were no future employment possibilities. In the debriefing, we asked workers about the extent to which they believed that there would be no future employment in our organization. Overall, 93.8 percent found our announcement credible in retrospect, and there were no significant differences between treatments (No-layoff 94.7 percent, Quasi-layoff 90.9 percent, Layoff 95.7 percent, t-test p-values $>0.353$ ). Moreover, no worker asked for further employment during our experiment.

Another concern could be that workers hoped for some recommendation from the management after the employment, and that getting such a recommendation was less likely when the employer had laid off some workers. However, none of our workers asked for a certificate of employment or recommendation.

Did the announcement of unfair layoffs signal a lack of management competence? The announcement of unfair layoffs may have signaled to workers that the management was struggling with the organization of the project. This in turn may have lowered their work motivation. To evaluate this option, we requested subjects to rate the management's competence on a scale from 1 (not competent at all) to 10 (highly competent). We made this request in the debriefing before informing workers that they had participated in an experiment. The average ratings are quite high and consistent across treatments: 8.1 points $(s d=1.9)$ in the No-layoff treatment, 8.2 points $(\mathrm{sd}=1.5)$ in the Quasi-layoff treatment, and 8.1 points $(\mathrm{sd}=1.6)$ in the Layoff treatment (MW-test p-values $>0.617$ ). Thus, the announcement of unfair layoffs had no significant impact on the workers' perception of the management's competence, ruling out that different perceptions might have driven the drop in performance in the Layoff treatment.

Did the announcement of unfair layoffs signal a lack of task meaning? Another alternative explanation for our main result could be that the announcement of unfair layoffs lowered the workers' perception of the importance of the task for the employer. Several papers show that task meaning matters for work performance. ${ }^{16}$ To rule out that our results might be driven by differing perceptions of task importance, we asked workers in the debriefing how important they believed the interviews to be for the employer, on a scale from 1 (not important at all) to 10 (very important). Again, we made this request before workers knew that they had participated in an experiment. We observe no statistically significant differences in the rating between treatments: The average rating is 7.9 points $(\mathrm{sd}=1.7)$ in the No-layoff treatment, 7.3 points $(\mathrm{sd}=1.9)$ in the Quasi-layoff treatment, and 7.2 points $(\mathrm{sd}=2.1)$ in the Layoff treatal. (2017). 
ment (MW-test p-values $>0.145)$. Thus, varying perceptions of the importance of the task cannot explain our main result either.

\section{Did the announcement of unfair layoffs signal that workers were too productive in the} first shift? Another potential side-effect of the announcement of unfair layoffs could be that workers believe that they were "too productive" in the first shift and that the employer reduced the staff size as a consequence. They may then conclude that working less is justifiable. To counter such beliefs, we provided each worker with a large number of phone numbers to call, which were impossible to complete within a single shift. Moreover, we asked workers, in the post-experimental survey, a number of questions referring to potential reasons why they performed better or worse in the second shift. In particular, we asked to what extent they agreed with the following statement: "I worked less in the second shift since my colleagues and I already performed very well in the first shift, so we could relax a bit". The scale was between 1 (do not agree) and 10 (fully agree). The average response to this statement was similar in all treatments and very low, indicating fairly strong disagreement with the statement: 2.1 points $(\mathrm{sd}=2.4)$ in the No-layoff treatment, 2.0 points $(\mathrm{sd}=1.8)$ in the Quasi-layoff treatment, and 2.2 points $(\mathrm{sd}=2.2)$ in the Layoff-treatment $(\mathrm{MW}$-test $\mathrm{p}$-values $>0.616)$. The performance reduction in the Layoff treatment therefore cannot be explained by a change in the perceived necessity to work hard.

Did we have spillover effects? One common concern in field experiments are spillover effects between treatments. It may be the case that workers in the No-layoff and Quasi-layoff treatments heard about the announcement of unfair layoffs from others and therefore responded by lowering their performance. This would mean that - if anything - we underestimate the effect of the announcement of unfair layoffs. The 12-percent performance reduction would then constitute a conservative estimate.

We implemented several measures to mitigate potential spillover effects and to control for them in the data. First, we isolated the different treatment groups. All workers who arrived at a certain time in the call-center were admitted to the same treatment. Second, we conducted the Layoff and Quasi-layoff treatment sessions after the bulk of the No-layoff sessions. Hence, while in principle there could be spillover effects between the Layoff and Quasi-layoff treatment, there is little scope for such effects between the No-layoff and Layoff treatment. Since we do not observe any significant performance differences between No-layoff and Quasilayoff, we conjecture that there were no large spillover effects between the Layoff and Quasilayoff treatments, because otherwise it would have been unlikely to observe the strong differences between Layoff and Quasi-layoff.

Additionally, we asked workers in the debriefing whether they knew other workers from the call-center. For each correct name, we paid them 0.50 Euros. We therefore received precise data about the social network in our workforce. Overall, 41.5 percent of the workers correctly named at least one co-worker. However, the large majority of workers who knew each other actually 87.8 percent - were employed in the same shift and thus in the same treatment, reduc- 
ing the potential for spillovers substantially. Only 12.2 percent of workers knew a co-worker from another treatment, but not a single one knew workers from more than one other treatment. Our results remain unchanged if we re-run our baseline regression and interact our treatment dummies (or shift dummies) with a dummy capturing whether a subject knew another worker from another treatment; see Table $\mathrm{O}$ in the Online Appendix. ${ }^{17}$ Hence, there is no evidence for significant spillover effects between treatments.

The alternative explanations discussed - and rejected - in this subsection make it plausible for us that the perception of unfair behavior of the employer towards co-workers drives the productivity losses in the Layoff treatment. In order to corroborate this interpretation of our main result, we approached two further subject pools in a survey and an experiment and asked for their assessment of our treatments and their predictions about the potential productivity effects of unfair layoffs. The next section presents the insights gained from these additional subject pools.

\section{How professional HR managers and university students asses- sed the layoffs}

\subsection{Vignette study with university students}

To study how impartial spectators would evaluate the layoffs, we conducted a vignette study (in the spirit of Kahneman et al., 1986, or Charness and Levin, 2000). Specifically, we measured the perceived fairness of hypothetical layoff scenarios using a between-subject approach. The baseline scenario (Scenario 1) reads as follows:

The economic survival of a company is threatened. It therefore lays off a number of workers. The selection of laid-off workers is random. The company complies to the legal standards for layoffs. How fair are the layoffs on a scale between 1 (very unfair) to 10 (very fair)?

We varied this scenario in the following ways: In Scenario 2, the survival of the company is not threatened (all else equal). In Scenario 3, the survival of the company is not threatened and the company lays off workers to save costs. This scenario corresponds to our field setting in the Layoff treatment. In Scenario 4, the survival of the company is not threatened, the company lays off workers to save costs, and it mostly lays off the least productive workers.

In total, 212 students from the University of Cologne participated in the vignette study. They were recruited with the help of ORSEE (Greiner, 2015) to complete our questionnaire in the experimental laboratory of the university. A large fraction of these students were working parttime at the time of the experiment, and most others had had part-time jobs in the past. Thus, this subject pool was familiar with working for a company and with the role of an employee. For this reason, we consider it as interesting to examine how they - being unaffected by our

175.6 percent of our workers knew someone who had been laid off. Our results remain unchanged if we exclude these workers. 
layoffs - assess the fairness of the layoffs and whether their assessment matches our workers' assessment.

The vignette study yielded the following results. In the baseline scenario 1 (company is threatened, random layoffs), the fairness of layoffs receives a mean rating of 4.3 points $(\mathrm{sd}=2.6)$. In Scenario 2 (company is not threatened, random layoffs) and in Scenario 3 (company is not threatened, cost savings, random layoffs), the average rating is 2.7 points each ( $\mathrm{sd}=1.6 \mathrm{in}$ Scenario 2, sd = 1.8 in Scenario 3). However, when layoffs are not random, but the least productive workers are laid off (Scenario 4), the mean rating increases to 5.0 points $(\mathrm{sd}=2.5)$, thus shifting in the direction of fairer behavior. Therefore, layoffs are judged as most unfair by participants of the vignette study when the company is not in economic troubles and layoffs are random. This is confirmed in statistical tests, as each of Scenarios 1 and 4 is significantly different from each of Scenarios 2 and 3 (all MW p-values $<0.010$ ), while there is no difference between Scenarios 1 and 4 (p-value $>0.100)$ and between Scenarios 2 and 3 (p-value $>$ $0.803)$.

Overall, our vignette study confirms the results from the post-experimental survey with our call-center workers. Random layoffs to cut costs are also judged as unfair by a completely unaffected sample of university students. Moreover, they also consider layoffs in companies that are not in economic trouble as unfair, which is similar to our workers' assessment. Next, we study how professional HR managers view our field experiment, and whether they would have anticipated the productivity effects of the employer's unfair behavior.

\subsection{Survey and experiment with professional HR managers}

Human resources managers are primarily concerned with optimizing employee performance. They are not only responsible for the design of employee benefits, recruitment and training, but also for organizational change which may involve the announcement and implementation of layoffs. Thus, they are in an ideal position to predict the consequences of our announcement of unfair layoffs.

In order to get access to professional HR managers, we collaborated with one of the largest associations of German human resources managers ("Deutsche Gesellschaft für Personalführung e.V.") and with one of the largest human resources magazines in Germany ("Personalwirtschaft"). Through both channels, HR managers were invited to participate online in a survey and an experiment.

In the instructions for the online experiment, we explained the design and procedures of our field experiment in detail. Subsequently, we informed the managers about the average number of calls in the first shift. Given that there had been no treatment differences, we communicated the average of 90 calls across all treatments. Then we asked HR managers to predict the average number of calls in the second shift separately for the No-layoff, Quasi-layoff and Layoff treatment. For that reason, we showed them the exact wording of the messages to workers be- 
fore the second shift (as shown in Figure 2 in Section 2.2). We presented a neutral framing for the three treatments (Group 1, 2, and 3) instead of the treatment abbreviations used in this paper.

To ensure that managers had an incentive to reveal their beliefs truthfully, we used the belief elicitation method from Gächter and Renner (2010). A manager earned 30 Euro for a correct guess; if he or she missed the true number of calls, the payoff was 20 Euro divided by the absolute distance between her predicted and the true average number of phone calls. A manager's total earnings was the payoff from one randomly chosen prediction (out of the three predictions for the three treatments), plus a fixed participation fee of 30 Euros. On average, managers earned 32.50 Euros in total.

Table 4: HR Managers' Predicted and Actual Mean Number of Phone Calls in the Second Shift

\begin{tabular}{lccc}
\hline \hline & Layoff & Quasi-layoff & No-layoff \\
\hline Predicitons & $87.5(9.9)$ & $89.4(14.6)$ & $74.5(20.3)$ \\
\hline Real Data & $80.9(34.7)$ & $82.2(23.3)$ & $75.3(31.4)$ \\
\hline \hline
\end{tabular}

Table 5: Opinion of HR Managers: Reasons for Lower Productivity in Layoff treatment

\begin{tabular}{lcc}
\hline \hline & $\begin{array}{c}\text { Most likely reason } \\
\text { (percent) }\end{array}$ & $\begin{array}{c}\text { Mean likelihood: each } \\
\text { reason (scale: 0 (unlikely) - } \\
\mathbf{1 0} \text { (very likely)) }\end{array}$ \\
\hline $\begin{array}{l}\text { "The workers expected future negative consequences } \\
\text { for themselves." }\end{array}$ & $7.0 \%$ & $\begin{array}{c}3.3 \\
(2.2)\end{array}$ \\
\hline & $2.3 \%$ & 3.1 \\
"The workers perceived the survey as unimportant." & & $(1.5)$ \\
\hline "The layoff of co-workers was considered as & $76.7 \%$ & 8.6 \\
unfair behavior of the employer." & & $\begin{array}{c}4.7 \\
(1.9)\end{array}$ \\
\hline $\begin{array}{l}\text { "The organizers of the phone survey were considered } \\
\text { as being incompetent." }\end{array}$ & $2.3 \%$ & $\begin{array}{c}4.6 \\
(1.8)\end{array}$ \\
\hline $\begin{array}{l}\text { "The workers thought that they were too productive } \\
\text { in the first shift." }\end{array}$ & $11.6 \%$ & \\
\hline \hline
\end{tabular}


After HR managers had entered their predictions for the average performance in the second shift, we revealed the true averages (as shown in Table 1) and then presented them with a list of five potential reasons for the lower performance in the Layoff treatment (see Table 5 below). First, we asked them which of those reasons they considered as the most likely reason for the significant drop in productivity in the Layoff treatment, and then we let them rate the likelihood with which each reason was responsible for the decline in productivity.

In total, 43 human resources managers participated in the online experiment. They worked in 23 different two-digit industries (NACE codes); ${ }^{18} 51$ percent of the managers were female; 83 percent of them worked in organizations that employed more than 500 workers. The managers had, on average, 7.6 years $(\mathrm{sd}=5.3)$ of professional experience in HR departments, and more than 70 percent of them had interviewed more than 50 job candidates (with an overall average number of interviews close to 300); 35 percent were involved several times in the implementation of layoffs, 21 percent were involved once, and 44 percent never.

Table 4 shows the HR managers' predictions. For the No-layoff and the Quasi-layoff treatments they expected a slight drop, although their estimate is not significantly different from 90. Actual performance data (shown in the second row) were lower (in the low 80s), but predictions and real data were not significantly different ( $p>0.190$ in both cases). The managers' predictions for the Layoff treatment are remarkably different, as they expected a large downward shift of productivity in this treatment. Their guess was, on average, 74.5 calls, which was very close to the actual average of 75.3 calls $(p=0.986)$. Importantly, the managers' predictions for the Layoff treatment (labelled Group 3 in their wording) was significantly lower than their predictions for the other two treatments (two-sided t-test; $p$-values $<0.001$ for both comparisons; the difference between No-layoff and Quasi-layoff is not significant). Hence, they were aware of the potentially large negative productivity shock that could occur from the announcement of unfair layoffs.

As a next step, we wanted to know from them - after revealing to each participant the true performance in the second shift of each treatment - why the workers in the Layoff treatment had reduced their performance. Table 5 shows the managers' responses. Looking at the first column, we note that 76.7 percent of them indicated "the layoff of co-workers was considered as unfair behavior of the employer" as the most likely reason for lower productivity. All other options listed in Table 5 were much less often regarded as the most important reason for the productivity decline in the Layoff treatment. The second-most frequently selected option with 11.6 percent only - was that workers had reduced their efforts because they had thought that they had been too productive in the first shift. While this is a legitimate conjecture, we had not found evidence in the post-experimental survey that workers felt that way (see Section $3.3)$.

The second column of Table 5 confirms the insight from the first column. HR managers rated the unfair behavior of employers by far as the factor that is most likely the reason for the de- 
cline in productivity in the Layoff treatment. The average rating of 8.6 is significantly larger than the average rating for any of the other four reasons ( $p$-values $<0.001$ in all cases). This confirms the importance that HR managers attach to unfair behavior of employers being the main driver of productivity shocks in our field experiment. Before concluding, we discuss in the next section how the productivity shocks on workers who are unaffected by the employer's unfair behavior relate to the size of the productivity shocks - reported in previous studies that are caused when workers are directly affected by an employer's unfair behavior.

\section{Putting our effect size into perspective - a comparison to productivity shocks of wage changes}

So far, we have shown that unfair layoffs of co-workers have strong negative effects on the productivity of unaffected workers. In this section, we want to put the observed effect size into perspective by comparing it to what is known from the literature about the productivity shocks of wage changes. We label the latter the direct effects of an employer's behavior on workers, and want to see how these direct effects relate to the indirect effects of an employer's behavior on workers.

Table 6: Effects of gift exchange on workplace performance

\begin{tabular}{|c|c|c|c|c|}
\hline Study & Intervention & Task & $\begin{array}{l}\text { Output } \\
\text { Change }\end{array}$ & Elasticity \\
\hline Gneezy and List (2006) ${ }^{[1]}$ & Pay raise USD 12 - USD 20 & Library Book Coding & $27 \%$ & 0,41 \\
\hline Gneezy and List (2006) ${ }^{[2]}$ & Pay raise USD 10 - USD 20 & Fundraising & $72 \%$ & 0,72 \\
\hline Kube et al. (2012) & Pay raise EUR 36 - EUR 43 & Library Book Coding & $5 \%$ & 0,26 \\
\hline Kube et al. (2013) & Pay cut EUR 15 - EUR 10 & Library Book Coding & $-20 \%$ & 0,6 \\
\hline Cohn et al. (2014) & Pay cut EUR 12 - EUR 9 & Selling Promotion Cards & $-15 \%$ & 0,6 \\
\hline Cohn et al. (2015) & Pay raise CHF $22-$ CHF 27 & Newspaper Distribution & $3 \%$ & 0,13 \\
\hline Gilchrist et al. (2016) & Pay raise USD 3 - USD 4 & Online Data Entry & $18 \%$ & 0,54 \\
\hline Esteves-Sorenson (2016) & Pay raise USD 12 - USD 20 & Data Entry & $2 \%$ & 0,03 \\
\hline DellaVigna et al. (2016) & Pay raise USD 7-USD 14 & Folding Envelopes & $2 \%$ & 0,02 \\
\hline DellaVigna et al. (2016) & Pay cut USD 7 - USD 3 & Folding Envelopes & $-2 \%$ & 0,04 \\
\hline This Paper & Layoffs & Phone Survey & $-12 \%$ & $0.60^{[3]}$ \\
\hline
\end{tabular}

[1] Study 1, first 90 minutes; [2] Study 2, first 3 hours; [3] this number is the percent change in output of the remaining workers over the percent change in total wages.

Table 6 provides an overview of how worker productivity has changed in various previous studies in reaction to a variation in their own wage. To compare the effect sizes across the different studies, we calculate for each study the wage elasticity of performance, which is 
percent change in output

$\overline{\text { percent change in total wage bill. }}$

For our field experiment, we define this elasticity as

$\underline{\text { percent change in output of remaining workers }}$

percent change in total wage bill.

From Table 6 we note that the wage elasticity of performance, if workers experience a wage increase, ranges from 0.02 to 0.72 . Wage cuts show an elasticity between 0.04 and 0.60 . In our case, we observe an elasticity of 0.60 , which is obviously at the upper bound of elasticities that apply when workers are directly affected by a wage change. Hence, even when wages and job prospects are unchanged, workers react sharply to an employer's behavior towards co-workers. In other words, the indirect effect of co-workers being laid off on the productivity of unaffected workers is substantial, and it should not be overlooked by employers.

\section{Conclusion}

In this paper, we measured how an employer's unfair behavior towards co-workers changes the productivity of unaffected workers. Studying this question seems of utmost importance from the perspective of organizations, as it reveals a frequently overlooked price that employers have to pay for unfair behavior. Of course, it is known that unfair wage cuts affect the productivity of affected workers in a negative way (see, e.g., Kube et al, 2013). Yet, it is much less clear whether and to what extent unfair behavior backfires on employers, in the sense that it also changes the behavior of unaffected workers. Measuring this latter aspect - which we call the indirect effect of unfair behavior - has been a major challenge because it is so difficult to test in the field. In a long-lived organization, any type of unfair behavior of employers towards co-workers will almost necessarily also change the unaffected workers' career prospects and beliefs about the employer's future behavior. As a consequence, any behavioral change of unaffected workers may be due to the expectation of getting affected in the future. The indirect effects that we are looking for can therefore only be cleanly measured if it is possible credibly to rule out future interaction. Our approach of founding a short-lived organization - by running a call-center where 195 workers had to conduct telephone interviews in two shifts - satisfies this condition to identify the indirect effect of employer behavior on unaffected workers. Before the second shift, we informed workers in our main treatment that 20 percent of the workforce had been laid off randomly to save costs.

The announcement of unfair layoffs triggered a reduction in the performance of unaffected workers of about 12 percent, compared to both a treatment without any layoffs and an additional control treatment where workers were informed about an equivalent reduction in staff size, without alluding to layoffs, to the attempt to save costs, or to the random determination of workers to be fired. The latter treatment shows that it is not the reduction in staff that causes the negative productivity shocks. In our Layoff treatment, we observed that gross working 
time and the quality of workers' output decreased and that workers were less satisfied with how management treated their co-workers, as a post-experimental survey revealed. Through the design of the workplace and the post-experimental survey we can rule out that the significant drop in performance in the Layoff treatment was due to altered beliefs about the management's competence, task meaning, or the anticipation of negative consequences in the future. Rather, the unfair nature of the employer's behavior towards co-workers was essential to understanding the negative productivity shock. A vignette study with 212 university students and a survey among 43 professional HR managers confirmed that the random firing of co-workers to save costs was seen as unfair and as the most likely reason for the strong decline in the productivity of unaffected workers. The HR managers predicted the magnitude of the productivity decline in the aggregate very well, showing that they had a sense for the potential consequences of an employer's unfair behavior on unaffected workers even in situations where the primary victims had already left the company and unaffected workers did not even have a chance to interact with them. This may explain why layoffs - which are often seen as unfair are usually circumvented by HR managers by relying on the natural fluctuation of the workforce to reduce the number of workers or by shifting the blame, for instance by blaming a previous CEO for the unfair action (i.e., the layoff). ${ }^{19}$

We consider it remarkable that our effect size of an employer's unfair behavior towards coworkers on unaffected workers is close to the upper bound of the direct effects of wage cuts on the productivity of affected workers. This suggests that the price of an employer's unfair behavior goes well beyond the potential tit-for-tat of directly affected workers. However, so far it was difficult to measure the price of the indirect effects on unaffected workers. Our method has allowed us to do so, and it has revealed that this price is substantial.

19 Bartling and Fischbacher (2012) present experimental evidence from the laboratory that shifting the blame works and reduces the extent of negative reciprocity. Fuss (2009) shows that firms often reduce their wage costs by relying on early retirement or the natural fluctuation of the workforce and by adjusting the amount of overtime hours or temporary workers rather than firing permanent workers. 


\section{References}

Akerlof, George (1982): "Labor Contracts as Partial Gift Exchange," Quarterly Journal of Economics, 97(4), 543-569.

Ariely, Dan, Emir Kamenica, and Drazen Prelec (2008): “Man's Search for Meaning: The Case of Legos," Journal of Economic Behavior and Organization, 67(3-4), 671-677.

Bartling, Björn, and Urs Fischbacher (2012): "Shifting the Blame: On Delegation and Responsibility," Review of Economic Studies, 79(1), 67-87.

Bloom, Nicholas, Benn Eifert, Aprajit Mahajan, David McKenzie, and John Roberts (2013): "Does Management Matter? Evidence from India," Quarterly Journal of Economics, 128 (1) (2013), 1-51.

Bloom, Nicholas, James Liang, John Roberts, and Zhichun Jenny Ying (2015): "Does Working from Home Work? Evidence from a Chinese Experiment," Quarterly Journal of Economics, 130(1), 165-218.

Bosch, Gerhard, and Claudia Weinkopf (2008): "Low-Wage Work in Germany," The Russell Sage Foundation Case Studies of Job Quality in Advanced Economics.

Breza, Emily, Supreet Kaur, and Yogita Shamdasani (forthcoming): "The Morale Effects of Pay Inequality," Quarterly Journal of Economics.

Chadi, Adrian, Mario Mechtel, and Vanessa Mertins (2016): "Should We Ban Smartphones from the Workplace to Increase Productivity? - Evidence from a Natural Field Experiment," working paper.

Chadi, Adrian, Sabrina Jeworrek, and Vanessa Mertins (2017): "When the Meaning of Work Has Disappeared: Experimental Evidence on Employees' Performance and Emotions," Management Science, 63(6), 1696-1707.

Chandler, Dana, and Adam Kapelner (2013): "Breaking Monotony with Meaning: Motivation in Crowdsourcing Markets," Journal of Economic Behavior and Organization 90, 123-133.

Charness, Gary, and Peter Kuhn (2007): "Doe Pay Inequality Affect Worker Effort? Experimental Evidence," Journal of Labor Economics, 25, 693-723.

Charness, Gary, and David Levine (2000): "When Are Layoffs Acceptable? Evidence from a Quasi-Experiment," Industrial and Labor Relations Review, 53(3), 381-400.

Cohn, Alain, Ernst Fehr, Benedikt Herrmann, and Frédéric Schneider (2014): "Social Comparison and Effort Provision: Evidence From a Field Experiment," Journal of the European Economic Association, 12(4), 877-898. 
Cohn, Alain, Ernst Fehr, and Lorenz Goette (2015): "Fair Wages and Effort Provision: Combining Evidence from a Choice Experiment and a Field Experiment," Management Science, 61(8), 1777-1794.

Datta, Deepak, James Guthrie, Dynah Basuil, and Alankrita Pandey (2010), "Causes and Effects of Employee Downsizing: A Review and Synthesis," Journal of Management, 26(1), 281-348.

DellaVigna, Stefano, John List, Ulrike Malmendier, and Gautam Rao (2016): "Estimating Social Preferences and Gift Exchange at Work," NBER Working Paper No. 22043.

Drzensky, Frank, and Matthias Heinz (2016): "The Hidden Costs of Downsizing," Economic Journal, 126(598), 2324-2341.

Esteves-Sorenson, Constança (forthcoming): "Gift Exchange in the Workplace: Addressing the Conflicting Evidence with a Careful Test," Management Science.

Friebel, Guido, and Paul Seabright (2011): "Do Women have Longer Conversations? Telephone Evidence of Gendered Communication Strategies," Journal of Economic Psychology, 32(3), 348-356.

Fuss, Catherine (2009): "What is the Most Flexible Component of Wage Bill Adjustment? Evidence from Belgium," Labour Economics, 16(3), 320-329.

Gächter, Simon, and Elke Renner (2010): "The Effects of (Incentivized) Belief Elicitation in Public Goods Experiments," Experimental Economics, 13(3), 264-377.

Gilchrist, Duncan, Michael Luca, and Deepak Malhotra (2016): "When 3+1>4: Gift Structure and Reciprocity in the Field," Management Science, 62(9), 2639-2650.

Gneezy, Uri, and John List (2006): "Putting Behavioral Economics to Work: Testing for Gift Exchange in Labor Markets Using Field Experiment," Econometrica, 74(5), 13651384.

Grant, Adam (2008): "The Significance of Task Significance: Job Performance Effects, Relational Mechanisms, and Boundary Conditions," Journal of Applied Psychology, 93(1), 108-124.

Greiner, Ben (2015): "Subject Pool Recruitment Procedures: Organizing Experiments with ORSEE," Journal of the Economic Science Association, 1(1), 114-125.

Harrison, Glenn, and John List (2004): "Field Experiments," Journal of Economic Literature, 42(4), 1009-1055. 
Hennig-Schmidt, Heike, Abdolkarim Sadrieh, and Bettina Rockenbach (2010): "In Search of Workers' Real-Effort Reciprocity - a Field and a Laboratory Experiment," Journal of the European Economic Association, 8(4), 817-837.

Kahneman, Daniel, Jack Knetsch, and Richard Thaler (1986): "Fairness as a Constraint on Profit Seeking: Entitlements in the Market," American Economic Review, 76(4), 728741.

Kosfeld, Michael, Susanne Neckermann, and Xiaolan Yang (2017): "The Effects of Financial and Recognition Incentives Across Work Contexts: The Role of Meaning," Economic Inquiry, 55(1), 237-247.

Kube, Sebastian, André Maréchal, and Clemens Puppe (2012): “The Currency of Reciprocity: Gift Exchange in the Workplace," American Economic Review, 102(4), 1644-1662.

Kube, Sebastian, André Maréchal, and Clemens Puppe (2013): "Do Wage Cuts Damage Work Morale? Evidence from a Natural Field Experiment," Journal of the European Economic Association, 11(4), 853-870. 


\section{Online Appendix}

This Online Appendix contains additional results and robustness checks. In Section A.1, we repeat the baseline regressions (see Table 2 and Table 3) for several variations of our main outcome measures (of phone calls and time spent on the phone). In Section A.2, we repeat the baseline regression using a number of alternative outcome measures (partly drawn from selfreports). In Section A.3, we consider the probability of a conducted interview rate as outcome measure. Section A.4 contains the regression analysis for the effect of the layoff announcement on workers' perception of the employer. In Section A.5, we compare the performance of the laid-off and the remaining workers in the Layoff treatment. In Section A.6, we present the baseline regression with controls for spillover effects. Section A.7 contains the interview questions. In Section A.8, we show a picture of a typical workplace in the call-center.

\section{A.1 Varying definitions of our two main outcome measures (numbers called, working time)}

In our baseline regression (in Table 2), we only counted phone calls where the call time was at least 15 seconds (if no client/answering device picked up the phone in the meantime). As a robustness check, we rerun our baseline regression using two alternative thresholds. First, we count all phone calls irrespective of the call time; and second, we set the threshold to $30 \mathrm{sec}-$ onds. As shown in the Tables A to D, changing the threshold does not affect our main results. 
Table A: Baseline Regression: Number of Calls

\begin{tabular}{|c|c|c|c|c|c|c|}
\hline \multirow[b]{2}{*}{ Specification } & \multicolumn{4}{|c|}{$\begin{array}{l}\text { Number of calls } \\
\text { (no call time threshold) }\end{array}$} & \multirow{2}{*}{$\begin{array}{c}\text { Numbers } \\
\text { called } t_{2} \\
(5)\end{array}$} & \multirow{2}{*}{$\begin{array}{c}\text { Difference } \\
\mathbf{t}_{\mathbf{2}}-\mathbf{t}_{\mathbf{1}} \\
(6)\end{array}$} \\
\hline & (1) & (2) & (3) & (4) & & \\
\hline Constant & $\begin{array}{c}91.893^{* * *} \\
(3.250)\end{array}$ & $\begin{array}{l}51.416 * * \\
(18.220)\end{array}$ & $\begin{array}{l}-10.615 \\
(30.487)\end{array}$ & $\begin{array}{c}93.176^{* * *} \\
(1.150)\end{array}$ & $\begin{array}{l}26.542 * * \\
(10.554)\end{array}$ & $\begin{array}{l}-5.607 * \\
(3.372)\end{array}$ \\
\hline $\mathrm{t}$ & $\begin{array}{l}-5.607^{*} \\
(3.238)\end{array}$ & $\begin{array}{l}-5.607 * \\
(3.279)\end{array}$ & $\begin{array}{l}-11.053 \\
(7.565)\end{array}$ & $\begin{array}{l}-5.607 * \\
(3.228)\end{array}$ & & \\
\hline No-layoff & $\begin{array}{l}-1.693 \\
(4.573)\end{array}$ & $\begin{array}{l}-2.634 \\
(4.879)\end{array}$ & $\begin{array}{c}2.939 \\
(12.457)\end{array}$ & & $\begin{array}{l}3.304 \\
(7.211)\end{array}$ & $\begin{array}{c}3.896 \\
(7.381)\end{array}$ \\
\hline No-layoff $\times \mathrm{t}$ & $\begin{array}{c}3.896 \\
(5.656)\end{array}$ & $\begin{array}{c}3.896 \\
(5.728)\end{array}$ & $\begin{array}{c}9.673 \\
(12.253)\end{array}$ & $\begin{array}{c}3.896 \\
(5.638)\end{array}$ & & \\
\hline Layoff & $\begin{array}{c}4.255 \\
(4.343)\end{array}$ & $\begin{array}{c}2.446 \\
(4.382)\end{array}$ & $\begin{array}{c}5.909 \\
(7.363)\end{array}$ & & $\begin{array}{c}-11.286^{*} \\
(5.695)\end{array}$ & $\begin{array}{c}-12.655^{* *} \\
(5.597)\end{array}$ \\
\hline Layoff $\times \mathrm{t}$ & $\begin{array}{c}-12.655^{* *} \\
(5.240)\end{array}$ & $\begin{array}{c}-12.655^{* *} \\
(5.307)\end{array}$ & $\begin{array}{c}-22.293^{* *} \\
(8.443)\end{array}$ & $\begin{array}{c}-12.655^{* *} \\
(5.224)\end{array}$ & & \\
\hline Numbers called $t_{1}$ & & & & & $\begin{array}{c}0.678 * * * \\
(0.104)\end{array}$ & \\
\hline $\mathrm{R}^{2}$ & 0.044 & 0.116 & 0.266 & 0.038 & 0.246 & 0.057 \\
\hline Sample size & 324 & 324 & 324 & 324 & 162 & 162 \\
\hline Subject fixed effect & No & No & No & Yes & No & No \\
\hline Age, Age squared & No & Yes & Yes & No & No & No \\
\hline Female & No & Yes & Yes & No & No & No \\
\hline German & No & Yes & Yes & No & No & No \\
\hline Student & No & Yes & Yes & No & No & No \\
\hline University degree & No & Yes & Yes & No & No & No \\
\hline Regular job & No & Yes & Yes & No & No & No \\
\hline Vocational training & No & Yes & Yes & No & No & No \\
\hline Unemployed & No & Yes & Yes & No & No & No \\
\hline Working day & No & No & Yes & No & No & No \\
\hline Time of day & No & No & Yes & No & No & No \\
\hline
\end{tabular}

Similar regression as in Table 2 . We count all phone calls, irrespective of the call time. ${ }^{*} \mathrm{p}<0.1$, $* * \mathrm{p}<0.05, * * * \mathrm{p}<0.01$. 


\begin{tabular}{|c|c|c|c|c|c|c|}
\hline \multirow[b]{2}{*}{ Specification } & \multicolumn{4}{|c|}{$\begin{array}{l}\text { Total time spent on the phone } \\
\text { (no call time threshold) }\end{array}$} & \multirow{2}{*}{$\begin{array}{c}\text { Working } \\
\text { time }_{2} \\
(5)\end{array}$} & \multirow{2}{*}{$\begin{array}{c}\text { Difference } \\
\mathbf{t}_{\mathbf{2}}-\mathbf{t}_{\mathbf{1}} \\
(6)\end{array}$} \\
\hline & (1) & (2) & (3) & (4) & & \\
\hline Constant & $\begin{array}{l}92.039^{* * *} \\
(3.352)\end{array}$ & $\begin{array}{l}41.840 * * \\
(19.209)\end{array}$ & $\begin{array}{l}-12.413 \\
(28.063)\end{array}$ & $\begin{array}{c}90.086^{* * *} \\
(1.015)\end{array}$ & $\begin{array}{c}5.814 \\
(8.962)\end{array}$ & $\begin{array}{c}-14.837 * * * \\
(2.874)\end{array}$ \\
\hline $\mathrm{t}$ & $\begin{array}{l}-14.704 * * * \\
(2.585)\end{array}$ & $\begin{array}{c}-14.704 * * * \\
(2.618)\end{array}$ & $\begin{array}{c}-19.733 * * * \\
(5.731)\end{array}$ & $\begin{array}{l}-14.704 * * * \\
(2.577)\end{array}$ & & \\
\hline No-layoff & $\begin{array}{l}-6.949 \\
(4.799)\end{array}$ & $\begin{array}{l}-5.787 \\
(5.026)\end{array}$ & $\begin{array}{c}10.245 \\
(11.433)\end{array}$ & & $\begin{array}{c}0.861 \\
(6.695)\end{array}$ & $\begin{array}{c}2.567 \\
(6.582)\end{array}$ \\
\hline No-layoff $\times \mathrm{t}$ & $\begin{array}{c}2.567 \\
(4.959)\end{array}$ & $\begin{array}{c}2.567 \\
(5.022)\end{array}$ & $\begin{array}{l}10.233 \\
(10.888)\end{array}$ & $\begin{array}{c}2.567 \\
(4.943)\end{array}$ & & \\
\hline Layoff & $\begin{array}{l}-0.059 \\
(4.551)\end{array}$ & $\begin{array}{l}-0.379 \\
(4.486)\end{array}$ & $\begin{array}{l}-3.033 \\
(7.499)\end{array}$ & & $\begin{array}{c}-11.921 * * \\
(4.533)\end{array}$ & $\begin{array}{c}-11.907 * * \\
(4.848)\end{array}$ \\
\hline Layoff $\times \mathrm{t}$ & $\begin{array}{c}-11.906^{* * *} \\
(4.536)\end{array}$ & $\begin{array}{c}-11.906^{* * *} \\
(4.595)\end{array}$ & $\begin{array}{c}-14.037 * * \\
(5.651)\end{array}$ & $\begin{array}{c}-11.906^{* * *} \\
(4.522)\end{array}$ & & \\
\hline Working time $t_{1}$ & & & & & $\begin{array}{c}0.754 * * * \\
(0.092)\end{array}$ & \\
\hline $\mathrm{R}^{2}$ & 0.120 & 0.227 & 0.349 & 0.109 & 0.374 & 0.050 \\
\hline Sample size & 324 & 324 & 324 & 324 & 162 & 162 \\
\hline Subject fixed effect & No & No & No & Yes & No & No \\
\hline Age, Age squared & No & Yes & Yes & No & No & No \\
\hline Female & No & Yes & Yes & No & No & No \\
\hline German & No & Yes & Yes & No & No & No \\
\hline Student & No & Yes & Yes & No & No & No \\
\hline University degree & No & Yes & Yes & No & No & No \\
\hline Regular job & No & Yes & Yes & No & No & No \\
\hline Vocational training & No & Yes & Yes & No & No & No \\
\hline Unemployed & No & Yes & Yes & No & No & No \\
\hline Working day & No & No & Yes & No & No & No \\
\hline Time of day & No & No & Yes & No & No & No \\
\hline
\end{tabular}

Similar regression as in Table 3 . We count all phone calls, irrespective of the call time. ${ }^{*} \mathrm{p}<0.1$, $* * \mathrm{p}<0.05, * * * \mathrm{p}<0.01$. 
Table C: Baseline Regression: Number of Calls

\begin{tabular}{|c|c|c|c|c|c|c|}
\hline \multirow[b]{2}{*}{ Specification } & \multicolumn{4}{|c|}{$\begin{array}{c}\text { Number of calls } \\
\text { (call time }>30 \text { seconds) }\end{array}$} & \multirow{2}{*}{$\begin{array}{c}\text { Numbers } \\
\text { called } t_{2} \\
(5)\end{array}$} & \multirow{2}{*}{$\begin{array}{c}\text { Difference } \\
\mathbf{t}_{\mathbf{2}}-\mathbf{t}_{\mathbf{1}} \\
(6)\end{array}$} \\
\hline & (1) & (2) & (3) & (4) & & \\
\hline Constant & $\begin{array}{c}84.089 * * * \\
(3.677)\end{array}$ & $\begin{array}{l}41.753 * * \\
(19.670)\end{array}$ & $\begin{array}{l}-39.038 \\
(31.640)\end{array}$ & $\begin{array}{c}84.605 * * * \\
(1.113)\end{array}$ & $\begin{array}{l}16.487 * \\
(8.373)\end{array}$ & $\begin{array}{c}-15.538^{* * *} \\
(3.055)\end{array}$ \\
\hline $\mathrm{t}$ & $\begin{array}{l}-8.679 * * \\
(3.354)\end{array}$ & $\begin{array}{l}-8.679^{*} \\
(3.397)\end{array}$ & $\begin{array}{l}-11.398 \\
(7.489)\end{array}$ & $\begin{array}{l}-8.679 * * \\
(3.343)\end{array}$ & & \\
\hline No-layoff & $\begin{array}{l}-2.312 \\
(4.816)\end{array}$ & $\begin{array}{l}-3.728 \\
(5.242)\end{array}$ & $\begin{array}{l}-12.914 \\
(11.583)\end{array}$ & & $\begin{array}{l}-0.858 \\
(7.644)\end{array}$ & $\begin{array}{c}2.194 \\
(6.419)\end{array}$ \\
\hline No-layoff $\times \mathrm{t}$ & $\begin{array}{l}-0.166 \\
(4.978)\end{array}$ & $\begin{array}{l}-0.166 \\
(5.870)\end{array}$ & $\begin{array}{c}-9.003 \\
(11.166)\end{array}$ & $\begin{array}{l}-0.166 \\
(5.777)\end{array}$ & & \\
\hline Layoff & $\begin{array}{c}3.075 \\
(4.757)\end{array}$ & $\begin{array}{c}1.666 \\
(4.643)\end{array}$ & $\begin{array}{c}1.507 \\
(8.821)\end{array}$ & & $\begin{array}{l}-9.991 * \\
(5.471)\end{array}$ & $\begin{array}{c}-11.782 * * \\
(4.941)\end{array}$ \\
\hline Layoff $\times \mathrm{t}$ & $\begin{array}{c}-10.912 * * \\
(4.978)\end{array}$ & $\begin{array}{c}-10.912^{* *} \\
(5.870)\end{array}$ & $\begin{array}{c}-15.790 * * * \\
(7.526)\end{array}$ & $\begin{array}{c}-10.912 * * \\
(4.963)\end{array}$ & & \\
\hline Numbers called $t_{1}$ & & & & & $\begin{array}{c}0.070 * * * \\
(0.089)\end{array}$ & \\
\hline $\mathrm{R}^{2}$ & 0.059 & 0.151 & 0.270 & 0.053 & 0.286 & 0.037 \\
\hline Sample size & 324 & 324 & 324 & 324 & 162 & 162 \\
\hline Subject fixed effect & No & No & No & Yes & No & No \\
\hline Age, Age squared & No & Yes & Yes & No & No & No \\
\hline Female & No & Yes & Yes & No & No & No \\
\hline German & No & Yes & Yes & No & No & No \\
\hline Student & No & Yes & Yes & No & No & No \\
\hline University degree & No & Yes & Yes & No & No & No \\
\hline Regular job & No & Yes & Yes & No & No & No \\
\hline Vocational training & No & Yes & Yes & No & No & No \\
\hline Unemployed & No & Yes & Yes & No & No & No \\
\hline Working day & No & No & Yes & No & No & No \\
\hline Time of day & No & No & Yes & No & No & No \\
\hline
\end{tabular}

Similar regression as in Table 2. Here we only count phone calls if the call time was at least 30 seconds (if no client or answering device has picked up the phone). ${ }^{*} \mathrm{p}<0.1, * * \mathrm{p}<0.05, * * * \mathrm{p}<0.01$. 
Table D: Baseline Regression: Total Time Spent on the Phone

\begin{tabular}{|c|c|c|c|c|c|c|}
\hline \multirow[b]{2}{*}{ Specification } & \multicolumn{4}{|c|}{$\begin{array}{l}\text { Total time spent on the phone } \\
\text { (call time }>30 \text { seconds) }\end{array}$} & \multirow{2}{*}{$\begin{array}{c}\text { Working } \\
\text { time }_{2} \\
(5)\end{array}$} & \multirow{2}{*}{$\begin{array}{c}\text { Difference } \\
\mathbf{t}_{\mathbf{2}}-\mathbf{t}_{\mathbf{1}} \\
(6)\end{array}$} \\
\hline & (1) & (2) & (3) & (4) & & \\
\hline Constant & $\begin{array}{c}89.848 * * * \\
(3.517)\end{array}$ & $\begin{array}{l}35.785^{* *} \\
(19.242)\end{array}$ & $\begin{array}{l}-16.706 \\
(29.097)\end{array}$ & $\begin{array}{l}87.652^{* * * *} \\
(1.022)\end{array}$ & $\begin{array}{c}6.569 \\
(8.586)\end{array}$ & $\begin{array}{c}-15.538^{* * *} \\
(3.055)\end{array}$ \\
\hline $\mathrm{t}$ & $\begin{array}{c}-15.538 * * * \\
(2.656)\end{array}$ & $\begin{array}{c}-15.538 * * * \\
(2.690)\end{array}$ & $\begin{array}{c}-20.108^{* * *} \\
(6.112)\end{array}$ & $\begin{array}{c}-15.538 * * * \\
(2.648)\end{array}$ & & \\
\hline No-layoff & $\begin{array}{l}-7.363 \\
(4.994)\end{array}$ & $\begin{array}{l}-6.397 \\
(5.227)\end{array}$ & $\begin{array}{c}8.847 \\
(12.508)\end{array}$ & & $\begin{array}{c}0.283 \\
(6.491)\end{array}$ & $\begin{array}{c}2.194 \\
(6.419)\end{array}$ \\
\hline No-layoff $\times \mathrm{t}$ & $\begin{array}{c}2.194 \\
(4.897)\end{array}$ & $\begin{array}{c}2.194 \\
(4.959)\end{array}$ & $\begin{array}{c}7.997 \\
(12.617)\end{array}$ & $\begin{array}{c}2.194 \\
(4.881)\end{array}$ & & \\
\hline Layoff & $\begin{array}{l}-0.398 \\
(4.640)\end{array}$ & $\begin{array}{l}-0.084 \\
(4.680)\end{array}$ & $\begin{array}{l}-5.139 \\
(7.651)\end{array}$ & & $\begin{array}{c}-11.880 * * \\
(4.595)\end{array}$ & $\begin{array}{c}-11.782 * * \\
(4.941)\end{array}$ \\
\hline Layoff $\times \mathrm{t}$ & $\begin{array}{c}-11.872 * * \\
(4.640)\end{array}$ & $\begin{array}{l}-11.782 * * \\
(4.699)\end{array}$ & $\begin{array}{c}-12.735^{* *} \\
(6.131)\end{array}$ & $\begin{array}{c}-11.782^{* *} \\
(4.625)\end{array}$ & & \\
\hline Working time $\mathrm{t}_{1}$ & & & & & $\begin{array}{l}0.754 * * * \\
(0.089)\end{array}$ & \\
\hline $\mathrm{R}^{2}$ & 0.122 & 0.238 & 0.346 & 0.110 & 0.382 & 0.055 \\
\hline Sample size & 324 & 324 & 324 & 324 & 162 & 162 \\
\hline Subject fixed effect & No & No & No & Yes & No & No \\
\hline Age, Age squared & No & Yes & Yes & No & No & No \\
\hline Female & No & Yes & Yes & No & No & No \\
\hline German & No & Yes & Yes & No & No & No \\
\hline Student & No & Yes & Yes & No & No & No \\
\hline University degree & No & Yes & Yes & No & No & No \\
\hline Regular job & No & Yes & Yes & No & No & No \\
\hline Vocational training & No & Yes & Yes & No & No & No \\
\hline Unemployed & No & Yes & Yes & No & No & No \\
\hline Working day & No & No & Yes & No & No & No \\
\hline Time of day & No & No & Yes & No & No & No \\
\hline
\end{tabular}

Similar regression as in Table 3. Here we only count phone calls if the call time was at least 30 seconds (if no client or answering device has picked up the phone). ${ }^{*} \mathrm{p}<0.1, * * \mathrm{p}<0.05, * * * \mathrm{p}<0.01$. 


\section{A.2 Alternative outcome measures}

In this section, we use a number of alternative outcome measures as dependent variable in our baseline regression. First, we use the number of self-reported phone calls. Since workers selfreport whether they have dialed existing or non-existing phone numbers, we run two separate regressions. In the first regression, we only include self-reported existing phone numbers; in the second regression, we additionally include non-existing phone numbers. Moreover, in our regressions with self-reported phone calls, we include the self-reported phone calls from the seven workers from the No-layoff treatment that we dropped in our baseline regression. Second, we use the number of calls divided by the total time workers spent on the phone, excluding all phone calls that resulted in an interview. Third, we use the gross working time, i.e., the duration between the start of the first phone call and the end of the last phone call that a worker conducted in a given shift. Fourth, we use the number of self-reported interviews. ${ }^{20}$

In Tables E to I, we present the regression results. The main results are mostly the same as in our baseline regressions. There are two exceptions. First, when we use the self- reported number of interviews as dependent variable, we find that our treatment effect is not always statistically significant at conventional significance levels (the p-values of our main coefficient of interest in the respective estimations lie between 0.11 and 0.16 ). However, the statistical power in these estimations is quite low since the variance in the number of interviews is large. Second, when we use the normalized number of calls, our treatment effect increases to 18 percent. Hence, our treatment effect of 12 percent discussed in the paper seems to be a conservative estimate. We conclude from these robustness checks that our main results are robust.

20 The interviews are self-reported, and we do not know whether a worker has really interviewed a client or faked an interview. However, based on the IT data from the call-center, we can check how long a worker has talked to a client on the phone. We find that most workers talk to a client between five and seven minutes when an interview is reported. In 5 percent of all self-reported interviews, we find that workers talked less than one minute to the client. It is unlikely that workers could conduct a full interview in less than a minute. Hence, we suspect that in such cases the worker faked an interview (or indicated a wrong outcome). We find that only a very small number of workers are responsible for the interviews that are likely to have been faked (the number is similar in all treatments). If we exclude those workers or if we exclude all interviews that did not last longer than one minute, our main regression results are unchanged. 


\begin{tabular}{|c|c|c|c|c|c|c|}
\hline \multirow[b]{2}{*}{ Specification } & \multicolumn{4}{|c|}{$\begin{array}{l}\text { Self-reported numbers called } \\
\text { (existing and non-existing numbers) }\end{array}$} & \multirow{2}{*}{$\begin{array}{c}\text { Numbers } \\
\text { called } t_{2} \\
(5)\end{array}$} & \multirow{2}{*}{$\begin{array}{c}\text { Difference } \\
\mathbf{t}_{\mathbf{2}}-\mathbf{t}_{\mathbf{1}} \\
(6)\end{array}$} \\
\hline & (1) & (2) & (3) & (4) & & \\
\hline Constant & $\begin{array}{l}238.679 * * * \\
\quad(9.191)\end{array}$ & $\begin{array}{l}218.274 * * * \\
(50.772)\end{array}$ & $\begin{array}{l}190.120 * * * \\
(62.574)\end{array}$ & $\begin{array}{l}237.738^{* * * *} \\
\quad(2.803)\end{array}$ & $\begin{array}{l}98.776^{* * *} \\
(24.157)\end{array}$ & $\begin{array}{l}-3.214 \\
(8.099)\end{array}$ \\
\hline $\mathrm{t}$ & $\begin{array}{l}-3.214 \\
(7.562)\end{array}$ & $\begin{array}{l}-3.214 \\
(7.656)\end{array}$ & $\begin{array}{l}-0.332 \\
(20.606)\end{array}$ & $\begin{array}{l}-3.214 \\
(7.539)\end{array}$ & & \\
\hline No-layoff & $\begin{array}{c}-8.255 \\
(12.133)\end{array}$ & $\begin{array}{c}-10.69 \\
(12.271)\end{array}$ & $\begin{array}{c}14.108 \\
(27.634)\end{array}$ & & $\begin{array}{c}3.706 \\
(14.117)\end{array}$ & $\begin{array}{c}7.234 \\
(14.501)\end{array}$ \\
\hline No-layoff $\times \mathrm{t}$ & $\begin{array}{c}7.233 \\
(13.161)\end{array}$ & $\begin{array}{c}7.234 \\
(13.323)\end{array}$ & $\begin{array}{c}12.115 \\
(31.913)\end{array}$ & $\begin{array}{c}7.234 \\
(13.121)\end{array}$ & & \\
\hline Layoff & $\begin{array}{c}4.521 \\
(12.622)\end{array}$ & $\begin{array}{c}0.602 \\
(12.758)\end{array}$ & $\begin{array}{c}20.854 \\
(17.476)\end{array}$ & & $\begin{array}{l}-32.870^{* *} \\
(12.883)\end{array}$ & $\begin{array}{r}-34.802 * * \\
(14.625)\end{array}$ \\
\hline Layoff $\times \mathrm{t}$ & $\begin{array}{c}-34.802^{* * *} \\
(12.963)\end{array}$ & $\begin{array}{c}-34.802 * * \\
(13.323)\end{array}$ & $\begin{array}{c}-72.211^{* * *} \\
(24.602)\end{array}$ & $\begin{array}{c}-34.802 * * \\
(12.924)\end{array}$ & & \\
\hline Numbers called $t_{1}$ & & & & & $\begin{array}{c}0.573 * * * \\
(0.095)\end{array}$ & \\
\hline $\mathrm{R}^{2}$ & 0.031 & 0.076 & 0.235 & 0.028 & 0.258 & 0.062 \\
\hline Sample size & 334 & 334 & 334 & 334 & 167 & 167 \\
\hline Subject fixed effect & No & No & No & Yes & No & No \\
\hline Age, Age squared & No & Yes & Yes & No & No & No \\
\hline Female & No & Yes & Yes & No & No & No \\
\hline German & No & Yes & Yes & No & No & No \\
\hline Student & No & Yes & Yes & No & No & No \\
\hline University degree & No & Yes & Yes & No & No & No \\
\hline Regular job & No & Yes & Yes & No & No & No \\
\hline Vocational training & No & Yes & Yes & No & No & No \\
\hline Unemployed & No & Yes & Yes & No & No & No \\
\hline Working day & No & No & Yes & No & No & No \\
\hline Time of day & No & No & Yes & No & No & No \\
\hline
\end{tabular}

Similar regression as in Table 2, except that we use the self-reported number of dialed numbers (irrespective of whether the number exists or not) as dependent variable. We dropped two observations from our Layoff treatment - one worker failed to self-report her phone calls in the first shift, and one worker failed to report them in the second shift. We include the self-reported phone calls from the seven subjects from our No-layoff treatment that we dropped in our baseline regressions in the paper. * $\mathrm{p}<0.1, * * \mathrm{p}<0.05, * * * \mathrm{p}<0.01$. 
Table F: Baseline Regression: Number of Calls (self-reported)

\begin{tabular}{|c|c|c|c|c|c|c|}
\hline \multirow[b]{2}{*}{ Specification } & \multicolumn{4}{|c|}{$\begin{array}{l}\text { Self-reported numbers called } \\
\text { (only existing numbers) }\end{array}$} & \multirow{2}{*}{$\begin{array}{c}\text { Numbers } \\
\text { called } t_{2} \\
(5)\end{array}$} & \multirow{2}{*}{$\begin{array}{c}\text { Difference } \\
\mathbf{t}_{\mathbf{2}}-\mathbf{t}_{\mathbf{1}} \\
(6)\end{array}$} \\
\hline & (1) & (2) & (3) & (4) & & \\
\hline Constant & $\begin{array}{l}106.107^{* * *} \\
\quad(3.911)\end{array}$ & $\begin{array}{c}91.880^{* * *} \\
(24.897)\end{array}$ & $\begin{array}{c}91.047 * * * \\
(30.671)\end{array}$ & $\begin{array}{l}105.280^{* * *} \\
(1.522)\end{array}$ & $\begin{array}{l}37.458^{*} \\
(19.681)\end{array}$ & $\begin{array}{l}-4.661 \\
(4.203)\end{array}$ \\
\hline $\mathrm{t}$ & $\begin{array}{l}-4.661 \\
(4.334)\end{array}$ & $\begin{array}{c}-4.661 \\
(4.387)\end{array}$ & $\begin{array}{l}-7.256 \\
(8.261)\end{array}$ & $\begin{array}{l}-4.661 \\
(4.321)\end{array}$ & & \\
\hline No-layoff & $\begin{array}{l}-1.299 \\
(5.385)\end{array}$ & $\begin{array}{l}-2.474 \\
(5.358)\end{array}$ & $\begin{array}{c}0.243 \\
(14.579)\end{array}$ & & $\begin{array}{c}6.722 \\
(7.146)\end{array}$ & $\begin{array}{c}7.238 \\
(7.450)\end{array}$ \\
\hline No-layoff $\times \mathrm{t}$ & $\begin{array}{c}7.238 \\
(8.244)\end{array}$ & $\begin{array}{c}7.238 \\
(8.346)\end{array}$ & $\begin{array}{c}16.593 \\
(22.007)\end{array}$ & $\begin{array}{c}7.238 \\
(8.219)\end{array}$ & & \\
\hline Layoff & $\begin{array}{l}-1.190 \\
(5.406)\end{array}$ & $\begin{array}{l}-2.391 \\
(5.514)\end{array}$ & $\begin{array}{l}-2.158 \\
(7.925)\end{array}$ & & $\begin{array}{c}-14.629^{* *} \\
(5.880)\end{array}$ & $\begin{array}{c}-14.156^{* *} \\
(6.551)\end{array}$ \\
\hline Layoff $\times \mathrm{t}$ & $\begin{array}{c}-14.156^{* *} \\
(6.209)\end{array}$ & $\begin{array}{c}-14.156^{* *} \\
(6.286)\end{array}$ & $\begin{array}{c}-28.838^{* * *} \\
(9.243)\end{array}$ & $\begin{array}{c}-14.156^{* *} \\
(6.191)\end{array}$ & & \\
\hline Numbers called $t_{1}$ & & & & & $\begin{array}{c}0.603 * * * \\
(0.198)\end{array}$ & \\
\hline $\mathrm{R}^{2}$ & 0.042 & 0.085 & 0.215 & 0.042 & 0.207 & 0.050 \\
\hline Sample size & 334 & 334 & 334 & 334 & 167 & 167 \\
\hline Subject fixed effect & No & No & No & Yes & No & No \\
\hline Age, Age squared & No & Yes & Yes & No & No & No \\
\hline Female & No & Yes & Yes & No & No & No \\
\hline German & No & Yes & Yes & No & No & No \\
\hline Student & No & Yes & Yes & No & No & No \\
\hline University degree & No & Yes & Yes & No & No & No \\
\hline Regular job & No & Yes & Yes & No & No & No \\
\hline Vocational training & No & Yes & Yes & No & No & No \\
\hline Unemployed & No & Yes & Yes & No & No & No \\
\hline Working day & No & No & Yes & No & No & No \\
\hline Time of day & No & No & Yes & No & No & No \\
\hline
\end{tabular}

Similar regressions as in Table E, except that we only include existing phone numbers. ${ }^{*} \mathrm{p}<0.1, * *$ $\mathrm{p}<0.05, * * * \mathrm{p}<0.01$. 
Table G: Baseline Regression: Number of Calls (normalized)

\begin{tabular}{|c|c|c|c|c|c|c|}
\hline \multirow[b]{2}{*}{ Specification } & \multirow[b]{2}{*}{ (1) } & \multicolumn{2}{|c|}{$\begin{array}{c}\text { Numbers called } \\
\text { (normal ized) }\end{array}$} & \multirow[b]{2}{*}{ (4) } & \multirow{2}{*}{$\begin{array}{c}\text { Numbers } \\
\text { called } t_{2} \\
(5)\end{array}$} & \multirow{2}{*}{$\begin{array}{c}\text { Difference } \\
\mathbf{t}_{\mathbf{2}}-\mathbf{t}_{\mathbf{1}} \\
(6)\end{array}$} \\
\hline & & (2) & (3) & & & \\
\hline Constant & $\begin{array}{c}0.540 * * * \\
(0.029)\end{array}$ & $\begin{array}{c}0.286^{*} \\
(0.151)\end{array}$ & $\begin{array}{c}0.289 \\
(0.250)\end{array}$ & $\begin{array}{c}5.104 * * * \\
(0.106)\end{array}$ & $\begin{array}{c}0.191 * * * \\
(0.059)\end{array}$ & $\begin{array}{l}-0.046^{*} \\
(0.026)\end{array}$ \\
\hline $\mathrm{t}$ & $\begin{array}{l}-0.461^{*} \\
(0.026)\end{array}$ & $\begin{array}{l}-0.046^{*} \\
(0.026)\end{array}$ & $\begin{array}{l}-0.064 \\
(0.062)\end{array}$ & $\begin{array}{l}-0.046^{*} \\
(0.026)\end{array}$ & & \\
\hline No-layoff & $\begin{array}{l}-0.021 \\
(0.040)\end{array}$ & $\begin{array}{l}-0.031 \\
(0.042)\end{array}$ & $\begin{array}{c}0.145 \\
(0.093)\end{array}$ & & $\begin{array}{l}-0.007 \\
(0.061)\end{array}$ & $\begin{array}{c}0.009 \\
(0.062)\end{array}$ \\
\hline No-layoff $\times \mathrm{t}$ & $\begin{array}{c}0.009 \\
(0.048)\end{array}$ & $\begin{array}{c}0.009 \\
(0.048)\end{array}$ & $\begin{array}{l}-0.065 \\
(0.095)\end{array}$ & $\begin{array}{c}0.009 \\
(0.047)\end{array}$ & & \\
\hline Layoff & $\begin{array}{c}0.034 \\
(0.039)\end{array}$ & $\begin{array}{c}0.019 \\
(0.039)\end{array}$ & $\begin{array}{c}0.040 \\
(0.067)\end{array}$ & & $\begin{array}{l}-0.081 * \\
(0.041)\end{array}$ & $\begin{array}{c}-0.096 * * \\
(0.038)\end{array}$ \\
\hline Layoff $\times \mathrm{t}$ & $\begin{array}{c}-0.096^{* *} \\
(0.040)\end{array}$ & $\begin{array}{c}-0.096^{* *} \\
(0.041)\end{array}$ & $\begin{array}{c}-0.140 * * \\
(0.063)\end{array}$ & $\begin{array}{c}-0.096^{* *} \\
(0.040)\end{array}$ & & \\
\hline Numbers called $t_{1}$ & & & & & $\begin{array}{c}0.560 * * * \\
(0.101)\end{array}$ & \\
\hline $\mathrm{R}^{2}$ & 0.043 & 0.095 & 0.231 & 0.035 & 0.226 & 0.042 \\
\hline Sample size & 324 & 324 & 324 & 324 & 162 & 162 \\
\hline Subject fixed effect & No & No & No & Yes & No & No \\
\hline Age, Age squared & No & Yes & Yes & No & No & No \\
\hline Female & No & Yes & Yes & No & No & No \\
\hline German & No & Yes & Yes & No & No & No \\
\hline Student & No & Yes & Yes & No & No & No \\
\hline University degree & No & Yes & Yes & No & No & No \\
\hline Regular job & No & Yes & Yes & No & No & No \\
\hline Vocational training & No & Yes & Yes & No & No & No \\
\hline Unemployed & No & Yes & Yes & No & No & No \\
\hline Working day & No & No & Yes & No & No & No \\
\hline Time of day & No & No & Yes & No & No & No \\
\hline
\end{tabular}

Similar regression as in Table 2, except that we use the number of calls divided by the total time workers spent on the phone (excluding all phone calls that resulted in an interview) as dependent variable. $* \mathrm{p}<0.1, * * \mathrm{p}<0.05, * * * \mathrm{p}<0.01$. 
Table H: Baseline Regression: Gross Working Time

\begin{tabular}{|c|c|c|c|c|c|c|}
\hline \multirow[b]{2}{*}{ Specification } & \multicolumn{4}{|c|}{ Grosswor king time } & \multirow{2}{*}{$\begin{array}{l}\text { Working } \\
\text { time } t_{2} \\
(5)\end{array}$} & \multirow{2}{*}{$\begin{array}{c}\text { Difference } \\
\mathbf{t}_{\mathbf{2}}-\mathbf{t}_{\mathbf{1}} \\
(6)\end{array}$} \\
\hline & (1) & (2) & (3) & (4) & & \\
\hline Constant & $\begin{array}{c}208.510^{* * *} \\
(1.353)\end{array}$ & $\begin{array}{c}178.468^{* * *} \\
(17.800)\end{array}$ & $\begin{array}{c}155.040 * * * \\
(26.177)\end{array}$ & $\begin{array}{c}207.080^{* * *} \\
(1.569)\end{array}$ & $\begin{array}{c}186.307^{* * *} \\
(61.045)\end{array}$ & $\begin{array}{c}-9.997 * * * \\
(4.123)\end{array}$ \\
\hline $\mathrm{t}$ & $\begin{array}{c}-9.997 * * * \\
(3.842)\end{array}$ & $\begin{array}{c}-9.997 * * \\
(3.891)\end{array}$ & $\begin{array}{c}-14.960 * \\
(7.860)\end{array}$ & $\begin{array}{c}-9.997 * * \\
(3.830)\end{array}$ & & \\
\hline No-layoff & $\begin{array}{l}-2.420 \\
(1.954)\end{array}$ & $\begin{array}{l}-0.846 \\
(2.562)\end{array}$ & $\begin{array}{c}2.461 \\
(7.286)\end{array}$ & & $\begin{array}{l}-4.031 \\
(8.422)\end{array}$ & $\begin{array}{l}-1.753 \\
(8.638)\end{array}$ \\
\hline No-layoff $\times \mathrm{t}$ & $\begin{array}{l}-1.752 \\
(6.809)\end{array}$ & $\begin{array}{l}-1.753 \\
(6.896)\end{array}$ & $\begin{array}{c}6.773 \\
(9.743)\end{array}$ & $\begin{array}{l}-1.753 \\
(6.787)\end{array}$ & & \\
\hline Layoff & $\begin{array}{l}-2.011 \\
(6.809)\end{array}$ & $\begin{array}{l}-1.017 \\
(2.302)\end{array}$ & $\begin{array}{c}5.416 \\
(5.641)\end{array}$ & & $\begin{array}{c}-23.343^{* * *} \\
(7.894)\end{array}$ & $\begin{array}{c}-21.449 * * * \\
(7.800)\end{array}$ \\
\hline Layoff $\times \mathrm{t}$ & $\begin{array}{c}-21.449 * * * \\
(7.418)\end{array}$ & $\begin{array}{c}-21.449 * * * \\
(7.513)\end{array}$ & $\begin{array}{c}-33.094 * * * \\
(8.787)\end{array}$ & $\begin{array}{c}-21.449 * * * \\
(7.395)\end{array}$ & & \\
\hline Working time $t_{1}$ & & & & & $\begin{array}{c}0.058 \\
(0.284)\end{array}$ & \\
\hline $\mathrm{R}^{2}$ & 0.153 & 0.194 & 0.324 & 0.152 & 0.070 & 0.060 \\
\hline Sample size & 324 & 324 & 324 & 324 & 162 & 162 \\
\hline Subject fixed effect & No & No & No & Yes & No & No \\
\hline Age, Age squared & No & Yes & Yes & No & No & No \\
\hline Female & No & Yes & Yes & No & No & No \\
\hline German & No & Yes & Yes & No & No & No \\
\hline Student & No & Yes & Yes & No & No & No \\
\hline University degree & No & Yes & Yes & No & No & No \\
\hline Regular job & No & Yes & Yes & No & No & No \\
\hline Vocational training & No & Yes & Yes & No & No & No \\
\hline Unemployed & No & Yes & Yes & No & No & No \\
\hline Working day & No & No & Yes & No & No & No \\
\hline Time of day & No & No & Yes & No & No & No \\
\hline
\end{tabular}

Similar regression as in Table 2, except that we use the duration between the start of the first phone call and the end of the last phone call that a worker conducts in a given shift as dependent variable. * $\mathrm{p}<0.1, * * \mathrm{p}<0.05, * * * \mathrm{p}<0.01$. 
Table I: Baseline Regression: Number of interviews

\begin{tabular}{|c|c|c|c|c|c|c|}
\hline \multirow[b]{2}{*}{ Specification } & \multicolumn{4}{|c|}{ Self-reported number of interviews } & \multirow{2}{*}{$\begin{array}{c}\text { Number of } \\
\text { interviews } t_{2} \\
\text { (5) }\end{array}$} & \multirow{2}{*}{$\begin{array}{c}\text { Difference } \\
\mathbf{t}_{\mathbf{2}}-\mathbf{t}_{\mathbf{1}} \\
(6)\end{array}$} \\
\hline & $(1)$ & (2) & (3) & (4) & & \\
\hline Constant & $\begin{array}{c}5.286^{* * *} \\
(0.270)\end{array}$ & $\begin{array}{l}2.561^{*} \\
(1.433)\end{array}$ & $\begin{array}{l}-0.089 \\
(2.275)\end{array}$ & $\begin{array}{c}0.827 * * * \\
(0.005)\end{array}$ & $\begin{array}{c}2.998 * * * \\
(0.382)\end{array}$ & $\begin{array}{c}-0.643 * * \\
(0.246)\end{array}$ \\
\hline $\mathrm{t}$ & $\begin{array}{c}-0.642 * * \\
(0.311)\end{array}$ & $\begin{array}{c}-0.643 * * \\
(0.315)\end{array}$ & $\begin{array}{l}-0.922 \\
(0.704)\end{array}$ & $\begin{array}{c}-0.643^{* *} \\
(0.310)\end{array}$ & & \\
\hline No-layoff & $\begin{array}{l}-0.486 \\
(0.457)\end{array}$ & $\begin{array}{l}-0.416 \\
(0.444)\end{array}$ & $\begin{array}{c}0.033 \\
(0.737)\end{array}$ & & $\begin{array}{l}-0.114 \\
(0.407)\end{array}$ & $\begin{array}{c}0.221 \\
(0.471)\end{array}$ \\
\hline No-layoff $\times \mathrm{t}$ & $\begin{array}{c}0.221 \\
(0.532)\end{array}$ & $\begin{array}{c}0.221 \\
(0.539)\end{array}$ & $\begin{array}{c}1.474 \\
(1.163)\end{array}$ & $\begin{array}{c}0.221 \\
(0.530)\end{array}$ & & \\
\hline Layoff & $\begin{array}{l}-0.122 \\
(0.429)\end{array}$ & $\begin{array}{l}-0.037 \\
(0.429)\end{array}$ & $\begin{array}{l}-0.507 \\
(0.696)\end{array}$ & & $\begin{array}{c}-0.769 * * \\
(0.323)\end{array}$ & $\begin{array}{l}-0.685 \\
(0.424)\end{array}$ \\
\hline Layoff $\times \mathrm{t}$ & $\begin{array}{l}-0.685 \\
(0.482)\end{array}$ & $\begin{array}{l}-0.685 \\
(0.488)\end{array}$ & $\begin{array}{l}-0.526 \\
(0.765)\end{array}$ & $\begin{array}{l}-0.685 \\
(0.480)\end{array}$ & & \\
\hline Number of interviews $t_{1}$ & & & & & $\begin{array}{c}0.311 * * * \\
(0.062)\end{array}$ & \\
\hline $\mathrm{R}^{2}$ & 0.046 & 0.110 & 0.201 & 0.039 & 0.127 & 0.023 \\
\hline Sample size & 324 & 324 & 324 & 324 & 162 & 162 \\
\hline Subject fixed effect & No & No & No & Yes & No & No \\
\hline Age, Age squared & No & Yes & Yes & No & No & No \\
\hline Female & No & Yes & Yes & No & No & No \\
\hline German & No & Yes & Yes & No & No & No \\
\hline Student & No & Yes & Yes & No & No & No \\
\hline University degree & No & Yes & Yes & No & No & No \\
\hline Regular job & No & Yes & Yes & No & No & No \\
\hline Vocational training & No & Yes & Yes & No & No & No \\
\hline Unemployed & No & Yes & Yes & No & No & No \\
\hline Working day & No & No & Yes & No & No & No \\
\hline Time of day & No & No & Yes & No & No & No \\
\hline
\end{tabular}

Similar regression as in Table 2, except that we use the number of self-reported interviews as dependent variable. ${ }^{*} \mathrm{p}<0.1, * * \mathrm{p}<0.05, * * * \mathrm{p}<0.01$. 


\section{A.3 Qualitative performance measure: Probability of conducting an interview}

In this section, we use the probability of conduction an interview as dependent variable in our regressions. The probability is the self-reported number of interviews divided by the selfreported number of phone calls in which a client picked up the phone. In the regressions, we use a "restricted" and an "expanded" sample. In the "restricted" sample, we dropped two observations from the Layoff treatment - one worker failed to self-report her phone calls in the first shift, and one worker failed to report them in the second shift. In the "expanded" sample, we use the same data as in the "restricted" sample, but we additionally include the self-reported phone calls from the seven workers from our No-layoff treatment that we dropped in our baseline regressions in the paper. 
Table J: Baseline Regression: Share of conducted interviews

\begin{tabular}{|c|c|c|c|c|c|c|}
\hline \multirow[b]{2}{*}{ Specification } & \multicolumn{4}{|c|}{ Share of conducted interviews } & \multirow{2}{*}{$\begin{array}{c}\text { Share } \\
t_{2} \\
(5)\end{array}$} & \multirow{2}{*}{$\begin{array}{c}\text { Difference } \\
\mathbf{t}_{2}-\mathbf{t}_{1} \\
(6)\end{array}$} \\
\hline & (1) & (2) & (3) & (4) & & \\
\hline Constant & $\begin{array}{c}0.179 * * * \\
(0.013)\end{array}$ & $\begin{array}{c}0.113^{*} \\
(0.062)\end{array}$ & $\begin{array}{l}0.177 * * \\
(0.073)\end{array}$ & $\begin{array}{c}0.174 * * * \\
(0.005)\end{array}$ & $\begin{array}{c}0.156^{* * *} \\
(0.018)\end{array}$ & $\begin{array}{c}0.024 \\
(0.016)\end{array}$ \\
\hline $\mathrm{t}$ & $\begin{array}{c}0.024 \\
(0.018)\end{array}$ & $\begin{array}{c}0.024 \\
(0.019)\end{array}$ & $\begin{array}{c}0.024 \\
(0.039)\end{array}$ & $\begin{array}{c}0.005 \\
(0.018)\end{array}$ & & \\
\hline No-layoff & $\begin{array}{l}-0.013 \\
(0.018)\end{array}$ & $\begin{array}{c}-0.004 \\
(0.018)\end{array}$ & $\begin{array}{l}-0.009 \\
(0.028)\end{array}$ & & $\begin{array}{c}-0.046^{* *} \\
(0.217)\end{array}$ & $\begin{array}{l}-0.036 \\
(0.025)\end{array}$ \\
\hline No-layoff $\times \mathrm{t}$ & $\begin{array}{l}-0.036 \\
(0.025)\end{array}$ & $\begin{array}{l}-0.036 \\
(0.025)\end{array}$ & $\begin{array}{c}0.013 \\
(0.048)\end{array}$ & $\begin{array}{l}-0.036 \\
(0.025)\end{array}$ & & \\
\hline Layoff & $\begin{array}{l}-0.003 \\
(0.019)\end{array}$ & $\begin{array}{c}0.007 \\
(0.019)\end{array}$ & $\begin{array}{l}-0.025 \\
(0.031)\end{array}$ & & $\begin{array}{c}-0.050 * * * \\
(0.019)\end{array}$ & $\begin{array}{c}-0.047 * * \\
(0.023)\end{array}$ \\
\hline Layoff $\times \mathrm{t}$ & $\begin{array}{l}-0.047 * \\
(0.025)\end{array}$ & $\begin{array}{c}-0.047 * * \\
(0.025)\end{array}$ & $\begin{array}{l}-0.022 \\
(0.048)\end{array}$ & $\begin{array}{l}-0.047^{*} \\
(0.025)\end{array}$ & & \\
\hline Conducted interviews $t_{1}$ & & & & & $\begin{array}{c}0.266 * * * \\
(0.071)\end{array}$ & \\
\hline $\begin{array}{l}\mathrm{R}^{2} \\
\text { Sample size }\end{array}$ & $\begin{array}{c}0.028 \\
320\end{array}$ & $\begin{array}{c}0.094 \\
320\end{array}$ & $\begin{array}{c}0.186 \\
320\end{array}$ & $\begin{array}{c}0.026 \\
320\end{array}$ & $\begin{array}{c}0.108 \\
160\end{array}$ & $\begin{array}{c}0.026 \\
160\end{array}$ \\
\hline Subject fixed effect & No & No & No & Yes & No & No \\
\hline Age, Age squared & No & Yes & Yes & No & No & No \\
\hline Female & No & Yes & Yes & No & No & No \\
\hline German & No & Yes & Yes & No & No & No \\
\hline Student & No & Yes & Yes & No & No & No \\
\hline University degree & No & Yes & Yes & No & No & No \\
\hline Regular job & No & Yes & Yes & No & No & No \\
\hline Vocational training & No & Yes & Yes & No & No & No \\
\hline Unemployed & No & Yes & Yes & No & No & No \\
\hline Working day & No & No & Yes & No & No & No \\
\hline Time of day & No & No & Yes & No & No & No \\
\hline
\end{tabular}

Similar regressions as in Table 2, except that the dependent variable is the self-reported number of interviews divided by the self-reported number of calls in which a client picked up the phone. We dropped two observations from our Layoff treatment - one worker failed to self-report her phone calls in the first shift and one worker failed to report them in the second shift. $* \mathrm{p}<0.1, * * \mathrm{p}<0.05, * * * \mathrm{p}<0.01$. 
Table K: Baseline Regression: Share of conducted interviews

\begin{tabular}{|c|c|c|c|c|c|c|}
\hline \multirow[b]{2}{*}{ Specification } & \multicolumn{4}{|c|}{ Share of conducted interviews } & \multirow{2}{*}{$\begin{array}{c}\text { Share } \\
t_{2} \\
(5)\end{array}$} & \multirow{2}{*}{$\begin{array}{c}\text { Difference } \\
\mathbf{t}_{\mathbf{2}}-\mathrm{t}_{\mathbf{1}} \\
(6)\end{array}$} \\
\hline & (1) & (2) & (3) & (4) & & \\
\hline Constant & $\begin{array}{c}0.180^{* * *} \\
(0.013)\end{array}$ & $\begin{array}{l}0.118^{*} \\
(0.061)\end{array}$ & $\begin{array}{c}0.101 \\
(0.074)\end{array}$ & $\begin{array}{c}0.173^{* * *} \\
(0.005)\end{array}$ & $\begin{array}{c}0.162^{* * *} \\
(0.018)\end{array}$ & $\begin{array}{c}0.024 \\
(0.016)\end{array}$ \\
\hline $\mathrm{t}$ & $\begin{array}{c}0.024 \\
(0.018)\end{array}$ & $\begin{array}{c}0.024 \\
(0.019)\end{array}$ & $\begin{array}{c}0.006 \\
(0.039)\end{array}$ & $\begin{array}{c}0.024 \\
(0.018)\end{array}$ & & \\
\hline No-layoff & $\begin{array}{l}-0.017 \\
(0.018)\end{array}$ & $\begin{array}{l}-0.008 \\
(0.017)\end{array}$ & $\begin{array}{l}-0.013 \\
(0.034)\end{array}$ & & $\begin{array}{c}-0.043^{* *} \\
(0.020)\end{array}$ & $\begin{array}{l}-0.029 \\
(0.024)\end{array}$ \\
\hline No-layoff × t & $\begin{array}{l}-0.030 \\
(0.025)\end{array}$ & $\begin{array}{l}-0.030 \\
(0.025)\end{array}$ & $\begin{array}{c}0.019 \\
(0.050)\end{array}$ & $\begin{array}{l}-0.030 \\
(0.250)\end{array}$ & & \\
\hline Layoff & $\begin{array}{l}-0.003 \\
(0.019)\end{array}$ & $\begin{array}{c}0.007 \\
(0.019)\end{array}$ & $\begin{array}{l}-0.026 \\
(0.031)\end{array}$ & & $\begin{array}{c}-0.050 * * * \\
(0.019)\end{array}$ & $\begin{array}{c}-0.047 * * * \\
(0.023)\end{array}$ \\
\hline Layoff $\times \mathrm{t}$ & $\begin{array}{l}-0.047^{*} \\
(0.025)\end{array}$ & $\begin{array}{l}-0.047^{*} \\
(0.025)\end{array}$ & $\begin{array}{l}-0.022 \\
(0.047)\end{array}$ & $\begin{array}{l}-0.047^{*} \\
(0.025)\end{array}$ & & \\
\hline Conducted interviews $t_{1}$ & & & & & $\begin{array}{c}0.234^{* * *} \\
(0.074)\end{array}$ & \\
\hline $\mathrm{R}^{2}$ & 0.027 & 0.089 & 0.178 & 0.022 & 0.092 & 0.022 \\
\hline Sample size & 334 & 334 & 334 & 334 & 167 & 167 \\
\hline Subject fixed effect & No & No & No & Yes & No & No \\
\hline Age, Age squared & No & Yes & Yes & No & No & No \\
\hline Female & No & Yes & Yes & No & No & No \\
\hline German & No & Yes & Yes & No & No & No \\
\hline Student & No & Yes & Yes & No & No & No \\
\hline University degree & No & Yes & Yes & No & No & No \\
\hline Regular job & No & Yes & Yes & No & No & No \\
\hline Vocational training & No & Yes & Yes & No & No & No \\
\hline Unemployed & No & Yes & Yes & No & No & No \\
\hline Working day & No & No & Yes & No & No & No \\
\hline Time of day & No & No & Yes & No & No & No \\
\hline
\end{tabular}

Similar regressions as in Table J, except that we additionally include the self-reported share of conducted interviews from the seven observations from our No-layoff treatment that we dropped in our baseline regressions in the paper. ${ }^{*} \mathrm{p}<0.1,{ }^{* *} \mathrm{p}<0.05,{ }^{* * *} \mathrm{p}<0.01$. 


\section{A.4 Worker perception - Survey}

In the post-experimental survey, we asked the workers how satisfied they were (i) with the working atmosphere in the call-center, (ii) the wage, (iii) the manager's behavior towards the worker him- or herself, and (iv) the manager's behavior towards the worker's colleagues. The scale ranged from 0 (not satisfied at all) to 10 (very satisfied). In this section, we use the satisfaction levels as dependent variable in our regressions (Table L and M).

Table L: Workers' Satisfaction with Employer

\begin{tabular}{lcccccc}
\hline \hline & \multicolumn{3}{c}{ Panel A: } & \multicolumn{3}{c}{ Panel B: } \\
Working athmosphere & \multicolumn{3}{c}{ Wage } \\
Specification & $(1 \mathrm{a})$ & $(2 \mathrm{a})$ & $(3 \mathrm{a})$ & $(1 \mathrm{~b})$ & $(2 \mathrm{~b})$ & $(3 \mathrm{~b})$ \\
\hline Constant & $10.820^{* * *}$ & $12.930^{* * *}$ & $13.008^{* *}$ & \multirow{2}{*}{$9.667^{* * *}$} & \multirow{2}{*}{$12.381^{* * *}$} & \multirow{2}{*}{$11.584^{* * *}$} \\
& $(0.622)$ & $(4.724)$ & $(5.014)$ & $(0.436)$ & $(3.102)$ & $(4.549)$ \\
No-layoff & 0.529 & 0.425 & 2.746 & 0.697 & 0.417 & 0.886 \\
& $(0.861)$ & $(0.808)$ & $(1.715)$ & $(0.677)$ & $(0.536)$ & $(1.207)$ \\
Layoff & -0.057 & -0.148 & 0.094 & $0.994^{* *}$ & $0.934^{*}$ & 0.751 \\
& $(0.813)$ & $(0.817)$ & $(0.946)$ & $(0.480)$ & $(0.536)$ & $(0.833)$ \\
\hline $\mathrm{R}^{2}$ & 0.001 & 0.021 & 0.086 & 0.009 & 0.058 & 0.097 \\
Sample size & 122 & 122 & 122 & 122 & 122 & 122 \\
\hline Age, Age squared & No & Yes & Yes & No & Yes & Yes \\
Female & No & Yes & Yes & No & Yes & Yes \\
German & No & Yes & Yes & No & Yes & Yes \\
Student & No & Yes & Yes & No & Yes & Yes \\
University degree & No & Yes & Yes & No & Yes & Yes \\
Regular job & No & Yes & Yes & No & Yes & Yes \\
Vocational training & No & Yes & Yes & No & Yes & Yes \\
Unemployed & No & Yes & Yes & No & Yes & Yes \\
Previous short-term jobs & No & Yes & Yes & No & Yes & Yes \\
Working day & No & No & Yes & No & No & Yes \\
Time of day & No & No & Yes & No & No & Yes \\
\hline \hline
\end{tabular}

Tobit regression. The dependent variables are the workers' responses to the questions "How satisfied were you with the working atmosphere in the call-center" (Panel A) and "How satisfied were you with the salary" (Panel B) in the post-experimental survey. Workers who did not participate in the postexperimental survey are excluded. All independent variables are defined in the same way as in our baseline regression. As an additional control, we include in the regression a dummy that is set to one if a worker was employed in other short-term employment relationships (zero otherwise); we asked this question in the post-experimental survey. ${ }^{*} \mathrm{p}<0.1,{ }^{*} * \mathrm{p}<0.05, * * * \mathrm{p}<0.01$. 


\begin{tabular}{lcccccc}
\hline \hline & \multicolumn{3}{c}{ Panel A: } & \multicolumn{3}{c}{ Panel B: } \\
& \multicolumn{1}{c}{ Behavior towardsworkers } & \multicolumn{2}{c}{ Behavior towardsco-workers } \\
Specification & $(1 \mathrm{a})$ & $(2 \mathrm{a})$ & $(3 \mathrm{a})$ & $(1 \mathrm{~b})$ & $(2 \mathrm{~b})$ & $(3 \mathrm{~b})$ \\
\hline Constant & $12.719^{* * *}$ & $14.631^{* * *}$ & $14.007^{* *}$ & $11.857^{* * *}$ & $11.373^{* * *}$ & \multirow{2}{*}{$10.704^{* *}$} \\
& $(0.872)$ & $(5.608)$ & $(5.730)$ & $(0.669)$ & $(4.050)$ & $(4.106)$ \\
No-layoff & -1.614 & -1.798 & -3.184 & -0.147 & -0.475 & 1.154 \\
& $(1.007)$ & $(1.017)$ & $(2.797)$ & $(0.890)$ & $(0.954)$ & $(1.773)$ \\
Layoff & -0.786 & -1.013 & -0.369 & $-1.464^{*}$ & $-1.836^{* *}$ & $-1.690^{*}$ \\
& $(0.837)$ & $(0.871)$ & $(1.376)$ & $(0.798)$ & $(0.827)$ & $(0.873)$ \\
\hline $\mathrm{R}^{2}$ & 0.007 & 0.038 & 0.103 & 0.010 & 0.034 & 0.130 \\
Sample size & 122 & 122 & 122 & 122 & 122 & 122 \\
\hline Age, Age squared & No & Yes & Yes & No & Yes & Yes \\
Female & No & Yes & Yes & No & Yes & Yes \\
German & No & Yes & Yes & No & Yes & Yes \\
Student & No & Yes & Yes & No & Yes & Yes \\
University degree & No & Yes & Yes & No & Yes & Yes \\
Regular job & No & Yes & Yes & No & Yes & Yes \\
Vocational training & No & Yes & Yes & No & Yes & Yes \\
Unemployed & No & Yes & Yes & No & Yes & Yes \\
Previous short-term jobs & No & Yes & Yes & No & Yes & Yes \\
Working day & No & No & Yes & No & No & Yes \\
Time of day & No & No & Yes & No & No & Yes \\
\hline \hline
\end{tabular}

Tobit regression. The dependent variables are the workers' responses to the questions "How satisfied were you with the management's behavior towards you" (Panel A) and "How satisfied were you with the management's behavior towards your co-workers" (Panel B) in the post-experimental survey. Workers who did not participate in the post-experimental survey are excluded. All independent variables are defined in the same way as in Table L. ${ }^{*} \mathrm{p}<0.1, * * \mathrm{p}<0.05, * * * \mathrm{p}<0.01$. 


\section{A.5 Performance of fired and remaining workers (during the first shift)}

Table N shows the first-shift performance of laid-off workers and remaining workers in the Layoff treatment.

Table N: Performance in First Shift of Layoff Treatment

\begin{tabular}{lccc}
\hline \hline Specification & $\begin{array}{c}\text { Remaining } \\
\text { workers } \\
(\mathrm{n}=62)\end{array}$ & $\begin{array}{c}\text { Laid off } \\
\text { workers } \\
(\mathrm{n}=26)\end{array}$ & $\begin{array}{c}\text { Remaining vs } \\
\text { laid off workers } \\
\text { p-value }\end{array}$ \\
\hline Time spent on phone (in minutes) & 91.0 & 88.4 & 0.438 \\
Numbers called & $(25.2)$ & -23.1 & \\
(call time $>$ 15 seconds) & 92.3 & 82.6 & 0.172 \\
Gross working time (in minutes) & $(22.9)$ & $(32.5)$ & \\
& 206.0 & 198.9 & 0.109 \\
Amount of dialed numbers & $(9.0)$ & $(33.8)$ & \\
(self-reported; existing \& non-existing) & 243.2 & 241.4 & 0.908 \\
Amount of dialed numbers & $(66.9)$ & $(65.1)$ & \\
(self-reported; only existing numbers) & 104.9 & 109.5 & 0.524 \\
Number of interviews & $(28.8)$ & $(34.0)$ & \\
(self-reported) & 5.1 & 4.3 & 0.156 \\
Number of interviews & $(2.6)$ & $(2.4)$ & \\
(self-reported; call-time $>$ one minute) & 4.8 & 4.2 & 0.294 \\
Share of conducted interviews (in percent) & $(2.6)$ & $(2.4)$ & \\
& $(17.6$ & 15.5 & 0.434 \\
\hline \hline
\end{tabular}

Self-reported amount of dialed numbers: We dropped one observation in the Layoff treatment. The subject did not make notes about her phone calls on the list in the first shift. 


\section{A.6 Controlling for spillover effects}

In Table $\mathrm{O}$, we re-run our baseline regression and interact our treatment dummies (or shift dummies) with a dummy capturing whether a subject knew another worker from another treatment.

Table O: Baseline Regression, Controlling for Spillovers

\begin{tabular}{|c|c|c|c|c|}
\hline \multirow[b]{2}{*}{ Specification } & \multicolumn{2}{|c|}{ Number of calls } & \multicolumn{2}{|c|}{ Time spent on phone } \\
\hline & (1) & (2) & (3) & (4) \\
\hline Constant & $\begin{array}{c}87.068 * * * \\
(4.052)\end{array}$ & $\begin{array}{c}86.006^{* * *} \\
(7.862)\end{array}$ & $\begin{array}{c}92.142 * * * \\
(4.016)\end{array}$ & $\begin{array}{c}86.616^{* * *} \\
(6.980)\end{array}$ \\
\hline $\mathrm{t}$ & $\begin{array}{l}-4.690 \\
(4.875)\end{array}$ & $\begin{array}{l}-5.438 \\
(4.815)\end{array}$ & $\begin{array}{l}-14.138 \\
(4.043)\end{array}$ & $\begin{array}{c}-14.223^{* * *} \\
(3.982)\end{array}$ \\
\hline No-layoff & $\begin{array}{l}-1.802 \\
(5.696)\end{array}$ & $\begin{array}{c}0.142 \\
(6.102)\end{array}$ & $\begin{array}{l}-8.046 \\
(6.120)\end{array}$ & $\begin{array}{l}-2.567 \\
(6.567)\end{array}$ \\
\hline No-layoff $\times \mathrm{t}$ & $\begin{array}{l}-7.497 \\
(8.721)\end{array}$ & $\begin{array}{l}-6.156 \\
(8.680)\end{array}$ & $\begin{array}{l}-2.714 \\
(7.704)\end{array}$ & $\begin{array}{l}-2.020 \\
(7.748)\end{array}$ \\
\hline Layoff & $\begin{array}{c}5.391 \\
(4.947)\end{array}$ & $\begin{array}{c}5.394 \\
(4.627)\end{array}$ & $\begin{array}{l}-0.861 \\
(5.085)\end{array}$ & $\begin{array}{c}2.017 \\
(4.879)\end{array}$ \\
\hline Layoff $\times \mathrm{t}$ & $\begin{array}{c}-13.163 * * \\
(6.167)\end{array}$ & $\begin{array}{c}-12.415^{* *} \\
(6.118)\end{array}$ & $\begin{array}{c}-12.291 * * \\
(5.481)\end{array}$ & $\begin{array}{c}-12.206^{* *} \\
(5.486)\end{array}$ \\
\hline $\begin{array}{l}\mathrm{R}^{2} \\
\text { Sample size }\end{array}$ & $\begin{array}{c}0.068 \\
268\end{array}$ & $\begin{array}{c}0.118 \\
268\end{array}$ & $\begin{array}{c}0.152 \\
268\end{array}$ & $\begin{array}{c}0.238 \\
268\end{array}$ \\
\hline Spillover & Yes & Yes & Yes & Yes \\
\hline Age, Age squared & No & Yes & No & Yes \\
\hline Female & No & Yes & No & Yes \\
\hline German & No & Yes & No & Yes \\
\hline Student & No & Yes & No & Yes \\
\hline University degree & No & Yes & No & Yes \\
\hline Regular job & No & Yes & No & Yes \\
\hline Vocational training & No & Yes & No & Yes \\
\hline Unemployed & No & Yes & No & Yes \\
\hline
\end{tabular}

Similar regressions as in specification 1 and 2 of the Tables 2 and 3; we additionally include (i) an interaction term of our Quasi-layoff treatment dummy and a spillover dummy; and (ii) an interaction term of our No-layoff treatment dummy and a spillover dummy. The spillover dummy is set to one if a worker mentions the name of at least one co-worker from another treatment in the debriefing (zero otherwise). Workers who did not participate in the debriefing are excluded. ${ }^{*} \mathrm{p}<0.1,{ }^{* *} \mathrm{p}<0.05, * * *$ $\mathrm{p}<0.01$. 


\section{A.7 Phone interview questions}

In the section, we provide a translation of our nationwide survey on refugee integration and engagement in volunteering.

1. We start with your opinion on the aid the German government is providing to integrate refugees into the German society. In your opinion, should this government aid be extended, remain the same, or be reduced? [Answer options: should be extended, should remain the same, should be reduced]

2. When it comes to the topic of refugees, do you worry about your economic situation? [Answer options: worry a lot; worry a bit; do not worry at all]

3. When it comes to the topic of refugees, do you worry about the evolution of crime in Germany? [Answer options: worry a lot; worry a bit; do not worry at all]

4. When it comes to the topic of refugees, do you worry about social cohesion? [Answer options: worry a lot; worry a bit; do not worry at all]

5. When it comes to the topic of refugees, do you worry about the migration to Germany? [Answer options: worry a lot; worry a bit; do not worry at all]

6. If someone does me a favor, I am willing to return this favor in kind. [Answer on a scale between 1 (does not apply at all) and 7 (fully applies)]

7. If I suffer from serious injustice, I would take revenge at any price at the next opportunity. [Answer on a scale between 1 (does not apply at all) and 7 (fully applies)]

8. If someone puts me in difficult conditions, I will do the same with this person. [Answer on a scale between 1 (does not apply at all) and 7 (fully applies)]

9. I exert serious effort to help someone who helped me in the past. [Answer on a scale between 1 (does not apply at all) and 7 (fully applies)]

10. If someone insults me, I will be offensive towards this person. [Answer on a scale between 1 (does not apply at all) and 7 (fully applies)]

11. I am willing to incur costs to help someone who helped me in the past. [Answer on a scale between 1 (does not apply at all) and 7 (fully applies)]

12. We return to the refugee topic. With how many refugees or refugee families did you interact on a personal level in the last six months? [Indicate number] 
13. Are you supporting refugees or have you been supporting refugees on a voluntary basis in the last six months? [Answer options: yes; no]

14. I am confident that the refugee integration will succeed in Germany. [Answer on a scale between 1 (does not apply at all) and 7 (fully applies)]

15. The integration of refugees matters to me. [Answer on a scale between 1 (does not apply at all) and 7 (fully applies)]

16. It matters to me that we develop a common sense for how we can live together as a society. [Answer on a scale between 1 (does not apply at all) and 7 (fully applies)]

17. I would be willing to contribute financially to the integration of refugees. [Answer on a scale between 1 (does not apply at all) and 7 (fully applies)]

18. I could imagine getting to know and supporting a refugee family from my region. [Answer on a scale between 1 (does not apply at all) and 7 (fully applies)]

19. There are many opportunities to help refugees. Since recently, there also is a webpage that allows you to register your offer to help refugees - free of charge and without any commitment. Charity organizations may request it on demand. Examples are shoes that you no longer use or the voluntary assistance with administrative issues. If you would like to know more about this, I can give you more information. [Answer options: Want to know internet address; want to know phone number; no interest]

20. In which year were you born? [Indicate year of birth]

21. Are you the last person in your household who celebrated his/her birthday? [Answer options: yes; no]

22. What is currently your professional situation? [Answer options: employed; student; vocational training; retiree; unemployed; other]

23. What is your educational background? [Answer options: completed primary school; secondary school certificate; general qualification for university entrance; university degree; still in school; other]

24. Were both of your parents born in Germany? [Answer options: yes; no] 


\section{A.8 Picture of a workplace}

Figure A.1: A picture of a typical workplace in our call-center.

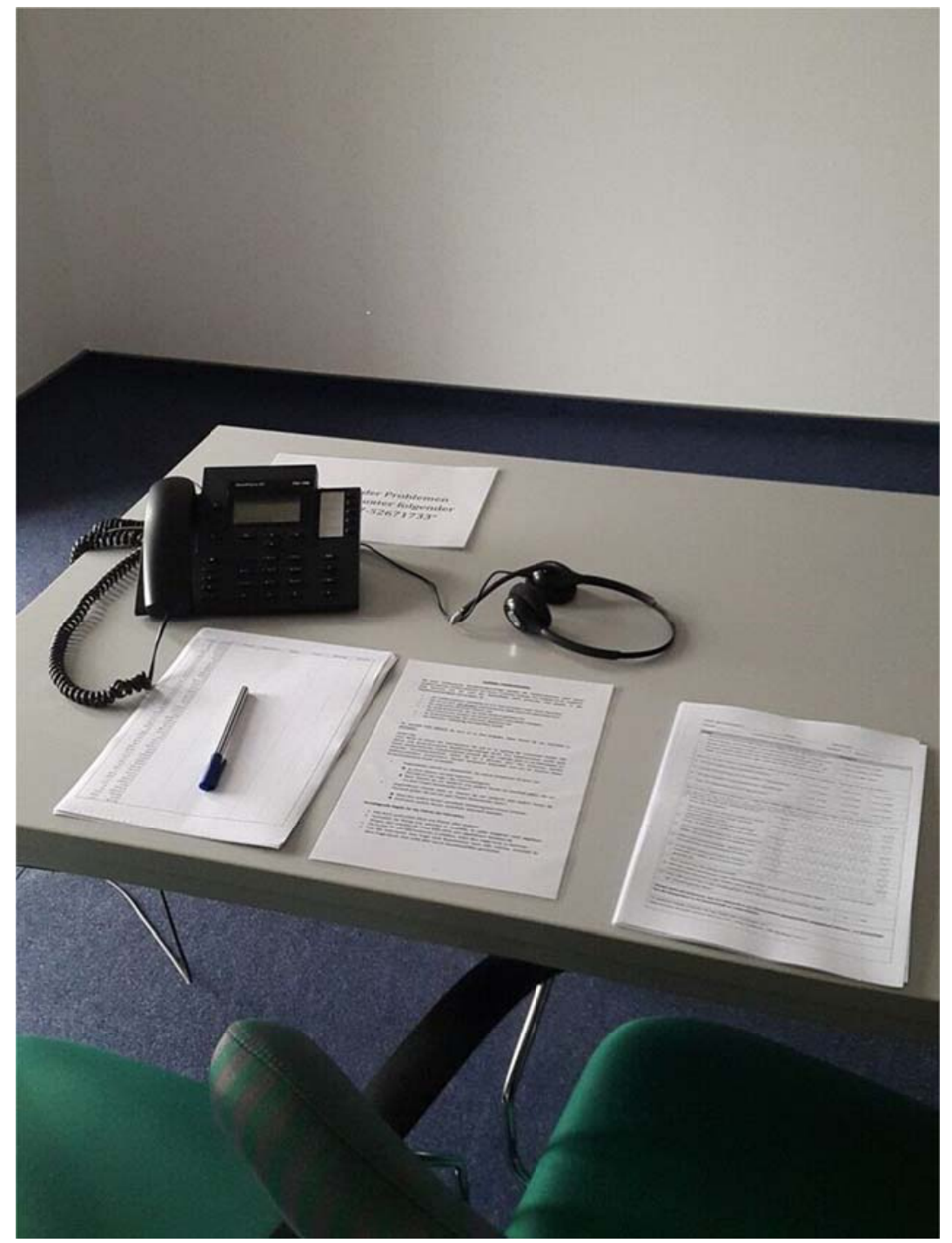

Figure A.1: Workplace in the call-center 